DOES LIMITED ACCESS

TO MORTGAGE DEBT EXPLAIN

2006

WHY YOUNG ADULIS LIVE WITH

THEIR PARENTS?

Nuno Martins and Einesto Villanueva.

Documentos de Trabajo.

N. 0628

baneo españa 
DOES LIMITED ACCESS TO MORTGAGE DEBT EXPLAIN WHY YOUNG ADULTS LIVE WITH THEIR PARENTS? 


\title{
DOES LIMITED ACCESS TO MORTGAGE DEBT EXPLAIN WHY YOUNG ADULTS LIVE WITH THEIR PARENTS?
}

\author{
Nuno Martins $\left({ }^{* *}\right)$ \\ UNIVERSIDAD DE LISBOA \\ Ernesto Villanueva $\left(^{* \star *}\right)$ \\ BANCO DE ESPAÑA
}

\begin{abstract}
${ }^{*}$ ) This work was done while the first author was working at the research department of the Bank of Portugal. We thank the comments of participants at the Bank of Spain, the Policy Evaluation Workshop in Seville, 2005, the 2005 joint SOLE-EALE in San Francisco, the 2004 LOWER Conference, the joint ECB-CEPR Conference on Labor Mobility in Europe, the 2004 EALE Conference in Lisbon, and seminars at FEDEA, Utrecht University and at Universitat Pompeu Fabra. Josh Angrist, Pau Baizan, Olympia Bover, Mário Centeno, Pierre Koning, Mary Gregory and Ana de Lamo gave very useful suggestions. We owe a special debt to Marco Manacorda for very detailed comments. All errors are ours. The views in this paper do not necessarily reflect those of the Bank of Spain or of the Bank of Portugal.

$\left.{ }^{(\star}\right)$ Department of Economics, Universidade Nova de Lisboa, Campus de Campolide, 1099-032 Lisboa, Portugal. Email: nmartins@fe.unl.pt.

$\left.{ }^{(* \star *}\right)$ Corresponding author. Affiliations: Bank of Spain, Universitat Pompeu Fabra and CREA. Address: Bank of Spain Servicio de Estudios (Research Department), Alcalá 48, 28014, Madrid, Spain. Email: ernesto.villanueva@bde.es.
\end{abstract}


The Working Paper Series seeks to disseminate original research in economics and finance. All papers have been anonymously refereed. By publishing these papers, the Banco de España aims to contribute to economic analysis and, in particular, to knowledge of the Spanish economy and its international environment.

The opinions and analyses in the Working Paper Series are the responsibility of the authors and, therefore, do not necessarily coincide with those of the Banco de España or the Eurosystem.

The Banco de España disseminates its main reports and most of its publications via the INTERNET at the following website: http://www.bde.es.

Reproduction for educational and non-commercial purposes is permitted provided that the source is acknowledged.

\section{(c) BANCO DE ESPAÑA, Madrid, 2006}

ISSN: 0213-2710 (print)

ISSN: 1579-8666 (on line)

Depósito legal: M.43908-2006

Imprenta del Banco de España 


\section{Abstract}

Young adults leave their parents' home at a higher rate in Northern Europe and the United States than in Southern Europe, with broad implications on labor mobility, intergenerational sharing of resources and on fertility. This paper assesses if differences in household structure can be traced back to restricted access to credit for the young. To study the causal impact of getting a loan on the probability of "leaving the nest", we exploit two reforms of a Portuguese program that subsidized interest rate on mortgages signed by low- and medium- income young adults. Using a unique dataset that merges a Labor Force Survey with administrative debt records, we estimate that getting a mortgage loan increases the rate of leaving home by between 31 and 54 percentage points. We combine those estimates with an European household panel to document that if our preferred estimates held for all countries, differential use of credit markets would explain between $16 \%$ and $20 \%$ of the North-South differences in home leaving.

Keywords: Living arrangements, Family Structure, Credit Markets.

JEL codes: D91, J12, H53. 


\section{Introduction}

There are large differences in household composition across OECD countries. While the proportion of Spanish, Italian and Portuguese young adults between 18 and 30 years of age who lived with their parents in 1997 exceeded $70 \%$, the corresponding number for the US or Northern European countries was below 50 $\%{ }^{1}$ Those patterns of household structure carry consequences for public policy. First, living in the house of the parents constrains young adults to look for jobs in local labor markets in a stage of the life-cycle when mobility across jobs is most important to find the best match with an employer (Neal, 1999). Second, determining if household structure is affected by poor labor or housing market conditions helps us to assess the insurance role of the extended family, and the incidence of policies that redistribute income across generations. ${ }^{2}$ Third, Southern European Countries like Spain and Italy have recently experienced a sharp decline in fertility rates. As the decisions of leaving the house of the parents, getting married and, subsequently having a child are lumped in Southern Europe, understanding the determinants of leaving the nest casts light on other long-term decisions of young adults (Billari et al., 2001). Finally, economic theory predicts that countries with higher percentage of coresident youth will also have higher aggregate savings rates (Alessie, Brugiavini and Weber, 2005). Our paper assesses if limited access to credit markets explains why young adults live with their parents.

A literature has documented that the probability of living with parents increases following negative income shocks (Rosenzweig and Wolpin, 1993, Card and Lemieux, 2000), is higher among the unemployed or among low-income groups (Martinez and Ruiz-Castillo, 2002, Aasve et al., 2002), and increases in regions with high renting or housing costs (Haurin et al., 1993, Martinez and Ruiz-Castillo, 2002). Manacorda and Moretti (forthcoming) present evidence suggesting that cohabitation with adult children is a normal good for Italian parents, who purchase it by providing their children with goods that cannot be acquired in the market. Becker et al. (2004) argue that cohabitation may be due to job insecurity experienced by young adults and/or their parents. Basically, when confronted with employment risk, young adults are likely to postpone irreversible decisions like establishing a new household. Giuliano (2004) documents that country-of-origin differences in household structure persist among second-generation migrants in the US. Combining that result with other sources of information, Giuliano concludes that international differences in cohabitation patterns are associated to differences in parental tolerance for the sexual behavior of young adult children.

\footnotetext{
${ }^{1}$ Estimates in Becker et al, (2004). Without aiming to survey the literature, cross-country differences in housing structure are noted among others by Manacorda and Moretti (2005), Becker et al. (2004), Iacovou (2001) and Baizan et al. (2001). While the proportion of young Southern Europeans living with their parents has increased over time, the differences between Southern European and Northern Europe are persistent: see Jurado (1999), or Baizán et al. (2001). In Martins and Villanueva (in press), we provide some summary statistics on the proportion of Portuguese young adults who live with their parents.

${ }^{2}$ See Rosenzweig and Wolpin, (1993, 1994). Mc Garry and Haider (2005) document that cohabitation with other earners is relatively more common among low-income women than among women further up in the income distribution. Gonzalez-Luna (2005) documents that cohabitation with parents partially accounts for the low incidence of single mothers in Southern Europe, a group of the population that is on the margin of poverty in Anglo-Saxon countries.
} 
Of course, each of those explanations is likely to play a role in the decision to leave the nest. We choose to focus on credit markets because of two reasons. First, Fogli (2004), Chiuri and Jappelli (2003), Del Boca and Lusardi (2003) and others have documented that Southern European's credit markets have traditionally been thin. During the $80 \mathrm{~s}$, average down payment (loan to value) ratios in Italy and Spain were larger (lower) than the European average. Furthermore, those limits to borrowing are specially likely to bite in Southern Europe, where individuals typically have had a strong bias for home ownership (see Bover, 2005). Second, getting a mortgage is an outcome that can be objectively measured in the data. Thus, if we are able to quantify the link between access to credit markets and nest-leaving, we can calculate how much of the cross-country variance of nest-leaving behavior is associated to variation in access to mortgage debt. That is not necessarily the case with subjective measures like job insecurity or with within-household transfers, that conventional surveys may not capture well.

Our paper builds on the insights of the literature that documents limited access to credit in Southern Europe, and uses a quasi-experimental setup to estimate what is the impact of getting a mortgage loan on the probability that a young adult leaves the household of his or her parents. ${ }^{3}$ We exploit the fluctuations in the cost of borrowing due to the reform and subsequent cancellation of a large program in Portugal called Crédito Bonificado (CB). The CB program was launched in 1986 and provided subsidies of up to $24 \%$ on interest rate payments on mortgage borrowing for relatively low- and medium income individuals. The program provided larger subsidies to young individuals in the lower three quartiles of the income distribution. A reform in 1998 introduced a country-wide ceiling on the price of the house that could be financed by the program; if the house price exceeded the ceiling by an euro, the individual would not get any subsidy at all. Further, in 2002 the program was cancelled. Our idea is that the introduction of a country-level ceiling will mostly affect eligible young individuals living in areas with high unit price of housing. The reason is that it is more difficult to find a suitable house whose price falls below the ceiling in an area with high unit costs of housing than in an area with low prices. Second, the cancellation of the CB program should have affected mostly young adults in low-price areas. The reason here is that, while young adults in low price areas could still profit from a scaled-down program by purchasing houses

\footnotetext{
${ }^{3}$ We have not found much literature on the impact of limited access to mortgage debt on the probability of establishing a new household. Chiuri and Jappelli (2003) document that individuals living in countries with thicker credit markets become home-owners earlier in the life-cycle. Vigdor (forthcoming) and others look at the impact of limits to borrowing on the timing of home ownership. Nevertheless, those papers usually take household formation as exogenous. A related literature examines coresidence with parents as the young adult's response to "bad" housing conditions, like housing purchase and rental prices or to the lack of public housing subsidies: Laferrére and Leblanc (2004), Ermisch and Di Salvo (1997), Martínez-Granado and Ruiz-Castillo (2002) and Haurin et al. (1993). Nevertheless, those papers do not consider availability of mortgage debt as a determinant of cohabitation. Finally, work somewhat related to ours is in Guiso and Jappelli (2002), who look at how transfers from parents may accelerate the age of home ownership.
} 
below the ceiling between 1999 and 2002, they would not be able to do that after the cancellation of the program.

We use some of the datasets and procedures developed by Martins and Villanueva (2005). There, we documented that the 1999 reform in the CB program affected negatively both the probability of getting a loan and the size of the loan taken. Unfortunately, whether or not improved access to credit markets affects real decisions of agents is an open debate. ${ }^{4}$ The results in Martins and Villanueva (2005) do not establish if favoured access to market debt shapes real decisions of individuals or if, on the contrary, it merely displaces other sources of borrowing. The present paper addresses that gap.

We think that our strategy has three main advantages. First, we are able to exploit what we think are unusual experiments; several reforms of a program that affected the access to credit markets of different groups of the population in different moments in time. Second, in many instances, testing implications of access to debt on the behavior of individuals is hampered by the fact that household surveys contain information on wealth only at the household level. Our work uses two samples, one of which links an employment survey with administrative records of individual debt: the 1998-2001 waves from the National Employment Survey in Portugal (Inquérito ao Emprego or IE) and the Census of Individual debt holding in Portugal between 1995 and 2002. That sample allows us to track the borrowing history of a young adult living with his or her parents. Third, combining our estimates of the response of household structure to access to credit markets with a longitudinal survey of European households (the European Community Household Panel or ECHP), we can provide back-of-the envelope measures of what fraction of the variance in nest leaving is explained by differential access to credit markets.

Our findings suggest that obtaining a loan increases the probability of establishing a new household by between 31 and 54 percentage points. Combining our preferred estimates with information on mortgage use and household leaving behavior from the ECHP, we obtain differences in the use of credit markets could explain by between $16 \%$ and $20 \%$ of the cross-European variance of the probability of establishing a new household.

The paper is organized as follows. Section 2 compares European patterns of nest-leaving and use of credit markets. Section 3 gives details on the Credito Bonificado Program and its likely impact on living arrangements and on mortgage use. Section 4 describes our data and the empirical specification, and Section 5 discusses our empirical results. Section 6 discusses the magnitude of the estimate. Section 7 concludes.

\footnotetext{
${ }^{4}$ Hurst and Lusardi (2004) find little evidence for the impact of borrowing constraints on becoming self-employed in the US. Carneiro and Heckman (2002) and Cameron and Taber (2004), again for the US, find that borrowing constraints do not affect educational choice.
} 


\section{Household formation in Europe and access to credit}

This section provides cross-country evidence suggesting that credit markets may play a role in determining household structure. That evidence will be subsequently combined with estimates of the impact of access to credit markets on "leaving the nest" to informally quantify the role of differences in credit markets in explaining differences in living arrangements.

The idea that credit markets play a role in explaining differences in household structure is not new. Fogli (2004) solves an overlapping generations model in which cohabitation of young adults with their parents arises as the optimal response to credit constraints, and sustains a politico-economic equilibrium with large degree of employment protection. Using cross-country plots, Fogli concludes that in countries with less developed credit markets (a) the legislation that protects the employment of mature workers is more strict and (b) relatively more young adults live with their parents. Chiuri and Jappelli (2003) and Del Boca and Lusardi (2003) document that there is a wide variation across OECD countries in the availability of long-term credit, as measured by (a) outstanding mortgage loans over GDP, (b) mortgage maturity and (c) the loan-to-value ratio. According to those measures, Spain and Italy have the lowest levels of availability of long-term credit debt in their samples.

Table 1 illustrates the cross-country relationship between nest leaving, the housing tenure status of adults who establish a new household and the use of mortgage debt in several European countries. We use a longitudinal dataset called the European Community Household Panel (ECHP). ${ }^{5}$ We selected individuals born between 1958 and 1977 in eleven European countries and who lived with their parents during the initial 1994 wave. A young adult is assumed to have left the house of parents if he or she moves to a different household where his or her parents are not present. The adult is dropped from the sample when that happens. ${ }^{6}$

We note three facts from Table 1 . First, Column 1 of Table 1 documents that the probability of leaving home over the course of one year is higher in Northern Europe than in Southern Europe. ${ }^{7}$ Young Danish are the most likely to leave the nest over the course of one year (21\%), while young Italians are the least likely to do so (5\%). Spain, Greece, Italy and Portugal have the lowest rates of nest leaving.

Second, there is a strong tendency in Southern Europe to establish a new

\footnotetext{
${ }^{5}$ The ECHP is a longitudinal dataset containing a common questionnaire for 15 European countries. It was started in 1994, gathering information on all individuals in interviewed households, and then followed all the individuals interviewed, including those who left the original household. It was discontinued in 2001. We present some summary statistics in the Appendix.

${ }^{6}$ In the remainder of the paper, we will use the terms "nest-leaving", "establishing a new household" and "leaving the parental house" interchangeably.

${ }^{7}$ Hereinafter, we consider "Northern European" the following countries: (ex-West) Germany, France, Belgium, the Netherlands, Ireland and the United Kingdom.
} 
household as a homeowner, rather than as a renter. Columns 3, 5 and 6 show the housing tenure status of young adults who left the parental household, and were tracked successfully by the ECHP (successful re-contact rates are shown in Column 2). In the four Southern European countries, the most common route to establish a new household is home-ownership. Why Southern Europeans are less likely to rent than Northern Europeans is a very important topic, but lies outside of the scope of this paper.

Finally, and conditional on leaving home as a home owner, Southern European young adults are much less likely to be paying a mortgage loan than Northern Europeans are. While among British young adults the fraction of new home owners who declare a mortgage loan among their housing costs is about $96 \%$, in Portugal or Spain the proportion is below $80 \%$, and it is very small in Italy (less than $30 \%){ }^{8},{ }^{9}$

The limited use of credit markets when Southern European young adults establish their own household can be explained by either supply or demand factors. A likely supply factor is the difficulty of repossession in case of default. ${ }^{10}$ Lenders could react to those costs by cream-skimming potential borrowers. Among the demand factors that limit the use of debt, one may claim that young Southern Europeans face high employment risk due to prevalent fixed-term contracts (Güell and Petrongolo, forthcoming, Jurado-Guerrero, 1999). Hence, young adults in Southern Europe may be reluctant to enter long-term commitments.

To assess to what extent demand or supply factors are the main driving forces, we pose the following question: imagine that we could observe a young adult in two situations: having, and not having access to a loan. What would be the increase in the probability of leaving the parental household between the two situations? If income and employment risk were the main reasons behind widespread cohabitation with parents, improved access to credit markets may not make much difference on household formation. If credit supply factors are the main factor, access to a loan could have a substantial impact on the probability of leaving the nest. To address the question, we examine the scaling down and subsequent cancellation of a program that subsidized mortgage borrowing

\footnotetext{
${ }^{8}$ We do not trust much the estimates for Greece, given the small sample size. For evidence from other datasets, Bover (2005) provides evidence consistent with ours; she compares wealth surveys from the United States, United Kingdom, Spain and Italy, and documents that the proportion of Italian and Spanish households holding mortgage debt is $11 \%$ and $30 \%$, respectively compared to $46 \%$ and $40.3 \%$ in the United States and United Kingdom.

${ }^{9}$ One can claim that non-borrower home -owners are young adults who have received either a house or substantial monetary transfers from their parents. The ECHP has limited information on such gifts. Yet, as an informal test, we have compared the median income of young adults who borrow and young adults who do not. In virtually all countries, the median income of young adults who do not borrow is lower than the median income of young adults who do borrow. Also, the median income of the parents of young adults who do not borrow is lower than the median income of the parents of young adults who borrow. As intergenerational transfers typically happen in the upper part of the income distribution, we doubt that the summary statistics in Column 4 of Table 1 reflect gifts.

${ }^{10}$ Chiuri and Jappelli (2003) document that the average duration of foreclosure proceedings in Italy and Spain exceeded 30 months in 1990, almost doubling the average duration in the rest of countries they examine. In its 2003 report, the European Mortgage Federation reports that repossession in Portugal in 2003 took on average between 4 and 5 years.
} 
in Portugal.

\section{A Portuguese case study: The Crédito Bonifi- cado Program}

In 1986 the Portuguese Government enacted Crédito Bonificado (CB), a program intended to increase the access to home ownership among young and lowincome individuals. The CB program provided various types of interest rate reductions at source to eligible households who financed with a mortgage loan the purchase of the house of residence. Only individuals with taxable income below a threshold, and who were not holding a mortgage debt were eligible for the program. The amount of the loan could not exceed the total value of the house. A person purchasing a house financed with a subsidized loan was not allowed to sell it within a period of five years, unless the person could prove that he or she needed to move for job tchanges.

The CB program provided four different subsidies on a proportion of the part of the monthly installment that reimbursed interest rate payments on a mortgage loan. The subsidy was directly given by the Portuguese Ministry of Finance to the lending institution and depended negatively on the (family size-) adjusted taxable income of the borrower. During the first two years of the life of a mortgage signed by an individual with taxable income below 3.25 times the annualized minimum wage, the highest initial subsidy amounted to $44 \%$ of the part of the installment that reimbursed interest rates payments. During the subsequent three years, the amount subsidized fell at a 1 percent rate each year: from $43 \%$ til $41 \%$. After the sixth year, the subsidy fell until at a 2 percent rate until exhaustion. Martins and Villanueva (2005), provide computations suggesting that a person granted with the highest subsidy and signing a mortgage with 25 year maturity and a $8 \%$ interest rate would experience a $24 \%$ reduction in the stream of payments. A person with the second highest subsidy would experience a $16 \%$ reduction, and the third and fourth subsidies resulted in $8 \%$ and $4 \%$, respectively. ${ }^{11}$

In the last quarter of 1998, the Portuguese Government implemented the first major reform of the program. The law mentioned two main reasons. First, according to the policy maker, the high interest rates that precluded access to housing in 1986 were no longer an obstacle in 1998 (nominal average interest rates on mortgage loans fell from 20 per cent in the late eighties to 8 per cent in 1998). The law implementing the reform also mentioned that the Government needed to cut public expenses. The 1999 reform established that to be eligible for the subsidy households satisfying the income requirements could not purchase a house above a ceiling. The particular limit depended on the taxable income and

\footnotetext{
${ }^{11}$ The subsidy was unlikely to be passed through higher borrowing rates. Aggregate records of average interest rates by loan type, show that in February 2001, the average interest rate charged to a person with a CB loan was 7.59 per cent, while the average interest rate charged to a non-CB loan was 7.43. From February 2001 until May 2002, the difference in the charged interest rates never exceeded 16 basis points.
} 
on the family size of eligible households, but not on the place of residence. ${ }^{12}$ For example, a just-married young adult with income below 3.25 times the (annualized) legal minimum wage could only be subsidized for the purchase of a house whose price was below 68,585 euro (nominal currency in of 1998). ${ }^{13}$ If the value of the house exceeded the value of the ceiling by one euro, the household was no longer eligible for any type of subsidy. ${ }^{14}$ The reform was effective in the second quarter of 1999, and hereinafter, we refer to it as the 1999 reform.

Finally, in 2002 the Portuguese Government launched a package of measures aimed at reducing public debt levels. Among other measures, like increasing the value-added tax, the Portuguese government precluded access to the program to new borrowers. Only those mortgage loans that customers and financial institutions could prove that they were bargaining upon by the time of the law change could still be subsidized by the program.

\subsection{Predicted effects of the 1999 reform and 2002 cancel- lation}

This section discusses how the 1999 and 2002 reforms changed incentives to borrow and establish a new household. Namely, we sketch the impact of the subsidy on the demand and supply of loans to understand what is the likely impact on the amount borrowed.

Demand side: Assume that young adults live for two periods, and that they can choose between staying or not with their parents in the first period. The total cost of purchasing a unit of housing consumption goods $h$ with a price of square unit $p$, in a model in which borrowing can only happen through mortgage borrowing is $\frac{p r}{1+r}$ where $r$ is the interest rate at which the young adult can borrow (see Henderson and Ioannides, 1983 for a derivation of this result). The borrowing rate is $r$ for an ineligible young adult, and $r(1-.24)$ for a young adult who is eligible for the highest subsidy. The 1999 reform introduced a severe nonlinearity in the budget constraint of an eligible young adult. Holding housing prices constant, the price of a unit of housing services financed with a mortgage loan would only vary with respect to the pre-reform situation if the individual wanted to purchase services above the uniform ceiling established by the reform $L$. If the young adult wanted to purchase housing services below the

\footnotetext{
${ }^{12}$ The limit for eligibles of class 1 was 62,350 euro, 68,585 euro, 81,055 euro or 87,290 euro if the family size was $1,2,3$ or 4 , and above, respectively. Conditional on family size, households eligible for the class 2 subsidy had higher limits: 69,832 euro ( 1 individual), 76,815 euro (2 individuals), 90,781 euro (three or four individuals) and 97,764 euro (five or more). The corresponding limits for class 3, were: 77,314 euro, 85,045 euro, 100,508 euro and 108,239 euro.

${ }^{13}$ We used a survey on wealth and income of Portuguese households (Inquérito ao Patrimonio Familias, IPEF 2000) to compute the average values of the houses for the various eligible classes and compare them to the 1999 ceilings. The average (median) value of a house bought before 1999 by households eligible for the maximum subsidy was 71,028 euro (62,350 euro). The limits introduced by the reform were in the $60 \mathrm{th}$ percentile of the distribution of the value of houses bought by eligibles before the 1999 reform, according to our computations.

${ }^{14}$ The preamble of the law emphasized the need to scale down the program, but did not discuss why establishing a ceiling was the best alternative available.
} 
threshold $L$, the pre- and post-reform cost of a unit of housing services would be the same (see Figure 1)

Obviously, the 2002 cancellation eliminated the discontinuity of the budget constraint. In the post-program situation, the price of the first unit of housing increased to $\frac{p r}{1+r}$ (see Figure 1, Panel B).

The 1999 and 2002 reforms should have affected differently the propensity to live with parents of different groups of youth. Given that the pre-reform price of real estate varied substantially across regions, the impact of the establishment of an uniform ceiling (the 1999 reform) will change with pre-reform prices. We assume that it is more difficult to find a house whose price falls below $L$ in a region with high price of houses than in a region with low prices (in the data, both price levels will be pre-reform). Thus, the 1999 reform should have limited more the access to mortgage debt among eligible young adults living in high-price regions than of eligible young adults in low price regions. Figure 2 presents two budget constraints, the one in the top (bottom) represents the budget constraint in a low (high) price region. In Panel A the indifference curve with the reservation utility level intersects with the post-reform budget, so the young adult can access higher utility levels in a new household than at parental home. In Panel B, the opposite is true. Both because of a steeper budget constraint and because of a tighter limit on the amount of subsidized housing services, the 1999 reform limits more the range of choices in a high price region. Thus, after 1999 the chances of staying with parents should have became lower in a region with low prices than in a region with high (pre-reform) prices.

Conversely, the 2002 cancellation should have affected individuals living in low pre-1999 reform price regions. Our conjecture is that those individuals were more likely to experience an increase in the unit cost of borrowing from the first unit after 2002 (they had the possibility of purchasing houses below the ceiling between 1999 and 2002). In other words, the 1999 reform and 2002 cancellation of the program affected eligible young adults in different ways. The 1999 reform increased the cost of borrowing among eligible individuals in highprice areas. Conversely, the 2002 reform should have increased relative more the cost of borrowing among young adults who are eligible for the program and lived in low-price areas that among young adults in high price areas. That heterogeneity in responses forms the basis of our empirical strategy. ${ }^{15,16}$

\footnotetext{
${ }^{15}$ There are several possible responses to the 1999 reform by young adults considering to establish their own household. The first is to still profit from the subsidy and to purchase a house whose price is below the limit $L$. The second response is to "leave the nest", but renting a house (instead of purchasing one). Finally, young adults with preferences for more expensive housing may postpone the decision of "leaving the nest" if the reservation utility from living with their parents exceeds the utility of either purchasing a house or of renting. Only if the third response is prevalent we could claim that young adults insure against increases in the cost of credit by staying with their parents.

${ }^{16}$ A further channel through which changes in the cost of borrowing would not affect cohabitation is the following. If decisions in the parental household seek to maximize total household income, an obvious way to do achieve this is to get children to fake the purchase the house of the parents and get the subsidy. This is not just a theoretical possibility, as one of the changes brought about by the 1999 reform was to avoid that type of behavior. If that behavior had been prevalent in the pre-reform situation, we would find little effect of changes
} 
Supply side: Mortgage loans are offered by private banks, who borrow at an interest rate $R_{0}$. Let us assume that an individual defaults for sure with probability $P$, and does not default with probability $1-P$. Let us also assume that banks cannot observe whether the individual is default-prone or not, but that if the individual defaults, the bank makes a loss $K$. Then, if banks make expected zero profits per loan, interest rates are set to $R=R_{0}+\frac{P}{1-P} K$. The introduction of a subsidy to borrowers may alter $P$, and the subsidy may not be effective if the probability of default of the new borrowers is much larger than that of the existing pool of borrowers (because $R$ will increase). We make the extreme assumption that $P$ is unaffected by the introduction of the subsidy. The rationale for that assumption is that the Portuguese government reimbursed the bank the full amount of the subsidy. Thus, from that perspective, the CB subsidy diminished the risk of lending to a young individual with uncertain future income stream at the market interest rate $R$. In sum, there were conditions that made the supply of funds elastic to changes in the interest rate, and the introduction (removal) of a subsidy to borrowers had the potential to increase (decrease) the number of borrowers.

We test two predictions of the impact of the 1999 and 2002 reforms on the borrowing behavior of eligible individuals:

- First, the 1999 reform should have led to a decrease in the rate of home leaving among eligible young adults in high- price areas, relative to eligible individuals in low- price areas.

- Relative to the pre-1999 reform situation, the differences in nest- leaving between eligible individuals in high- and low- price areas should have disappeared after the cancellation of the program.

Note that eligibles experimented an increase in the marginal cost of the first unit of housing services between the pre- 1999 regime and the post 2002 one (the unit cost increased from $\frac{p r(1-.24)}{1+r(1-.24)}$ to $\frac{p r}{1+r}$ ). Nevertheless, within the group eligibles, the relative cost of the first unit of housing both in high and low-price regions was the same pre-1999 $\left(\frac{p r(1-.24)}{1+r(1-.24)}\right)$ and post-2002 $\left(\frac{p r}{1+r}\right)$. The second test exploits that absence of difference across locations.

Two additional notes are in order prior to discussing the empirical strategy. First, our strategy leads to a reduced-form estimate of the impact of changing access to credit on the probability of living with parents. The reduced form estimates may also pick up effects in living arrangements induced by the behavior of housing prices (in principle, both the mean and the distribution of housing prices should have been affected by the program). We estimate some general equilibrium effects on prices in the working paper version of Martins and Villanueva (2005), and briefly summarize the results in the robustness subsection.

Second, what can we learn about family motives for providing shelter for their children? Manacorda and Moretti (forthcoming) test if parents are altruistic toward their adult children using information on the sign of the relationship

in the cost of credit on cohabitation. 
between household structure and parental income. The focus of this paper is to measure to what extent young adults' living arrangements respond to limitations in the access to mortgage borrowing, and we do not explicitly test any model of parental preferences.

\section{The Data}

We use two datasets. The first is drawn from a Portuguese quarterly employment survey called Inquérito ao Emprego (IE), that spans the period between 1998 and 2004. IE is rotating panel that follows respondents for at most six consecutive quarters, and includes information on household composition and labor earnings for each individual in the household. This survey is the Portuguese version of the Current Population Survey in the US.

We select individuals who are between 18 and 37 years of age, are not heads of household in the first quarter they are observed, and are not self-employed. We also exclude individuals whose reported labor income falls short of the annualized minimum yearly wage. We chose 18 as the minimum age based on the strikingly low percentage of eligible young adults who go to college: below $4 \%$ (the proportion among non-eligibles is much larger: $52 \%$ ).

Households are followed for at most 6 quarters, and between 1998 and 2002 a random fraction of $1 / 6$ th of households was dropped from the sample every quarter. For the refreshment sample entering in 2003, the fraction dropped each quarter increased to $1 / 5$ th. We infer nest-leaving by tracking individuals within households that stay in the sample. Only households who are interviewed for at least two consecutive quarters are used (i.e., we use 5/6ths of the IE sample up to 2003, and 4/5ths in 2003 and 2004). We assume that a young adult who lived with his or her parents in period $q$ has "left the nest" in that quarter $q$ if (a) the household of the parents stays in the sample in quarter $q+1$ and (b) the young adult is no longer a member of that household in period $q+1 .^{17}$ Unfortunately and like many employment surveys, the IE survey does not track individuals who leave the original household into their new one.

Our measure of nest-leaving can be affected by attrition at the household level, as we can only determine that a young adult left the parental household if the household of the parents is successfully tracked in two subsequent periods. We have not addressed the issue of conditional household attrition, that can also plague previous work with the IE that has exploited its panel aspect to analyze job flows (Blanchard and Portugal, 2001). At any rate, we think it is unlikely that attrition from the panel changed systematically with our key covariates: eligibility, location and the timing of reforms.

The first sample contains 35,624 individual-quarter observations on 9,314 young individuals between 18 and 37 years of age. The summary statistics of

\footnotetext{
${ }^{17}$ The IE considers that young adults who leave temporarily the household of their parents either to study or to do the military service are still household members. Also, note that most Portuguese young adults who attend college do not necessarily leave the household of their parents, but attend college in the city of residence of their parents.
} 
that sample are described in Panel A of Table 2. The probability of leaving the house of the parents in our sample is $2.29 \%$ per quarter, and decreases with eligibility for higher subsidies (between $2.96 \%$ among non-eligibles to $2.14 \%$ among eligibles for the highest subsidy). ${ }^{18}$ Translating the quarterly estimates into yearly ones yields a probability of leaving the nest in a year of 9.2 percent, above the 6.5 percent that we have estimated in Portugal using the European Household Panel. One should keep in mind that our sample excludes young adults with zero labor income, who are less likely to leave the nest.

The second sample matches the employment survey IE and administrative records of debt between 1998 and 2001. Whenever an individual in Portugal signs a loan with a credit agency, the institution is legally obliged to report the amount of that loan (and its subsequent evolution) to the Bank of Portugal. The resulting dataset is called the Central de Risco de Credito (CRC hereinafter). The Bank of Portugal has matched respondents of the 1998 -2001 surveys of the IE to the CRC panel between 1995 and 2002 using the NUTS-III region of residence, the exact date of birth and gender. We infer a new loan from increases in the individual stock of debt of at least 5,000 euro between the first quarter of 1997 and the first quarter of 1999 (for individuals interviewed before 2000), and between the first quarter of 2000 and the first quarter of 2002, for individuals interviewed after 2000. ${ }^{19}$ The reason for those time limits is that getting a loan is a low-probability event, so we chose wide pre- and post-reform time limits to maximize the probability of observing a loan. We also avoided considering the borrowing behavior in the last three quarters of 1999 , that were a period of high borrowing and of transition between the pre- and post- 1999 reform.

As discussed in Section 3, a key variable in our analysis is whether an individual lived in a "high-price" area prior to the passage of the 1999 reform. As the regional unit, we used the "county", the NUTS-III level of regional disaggregation. ${ }^{20}$ There are 311 counties in Portugal, with a median extension of 501 squared kilometers. To obtain the pre- 1999 median price of the housing squared meter, we have combined regional measures of prices that the Portuguese Statistical Agency started collecting in 2001 and quality-unadjusted measures of the increase in housing prices in some counties between 1995 and 2001, as provided by a real estate agency (Confidencial Imobiliario). ${ }^{21}$ The summary statistics

\footnotetext{
${ }^{18}$ The probability of nest-leaving increases with income and the relationship with age displays an inverse $U$ and is highest among females. Those patterns are very similar to regressions done in the European Household Panel, and other work about nest leaving (Billari et al. 2001). That correspondance makes us confident about our measure of nest-leaving.

${ }^{19}$ We have also experimented with a minimum amount of 7,500 euro, without much effect on the results. The advantage of this second sample is that it allows us to track the borrowing behavior of young adults around the time of leaving the parental household.

${ }^{20} \mathrm{We}$ inferred the county of actual residence of the household from the relationship between the code of the household interview number in IE and the more aggregated NUTS-III classification. The correspondence between both codes was provided by the Portuguese Statistical Agency (Instituto Nacional de Estadistica). Prior to 2001, the IE also contained a question about the place of residence in the previous year with NUTS-III level of disaggregation.

${ }^{21}$ Unfortunately, the private agency contains measures of the price of real estate for counties that contain $72 \%$ of the individuals in our sample (presumably, in the rest of the counties
} 
of the matched sample are described in Panel B of Table 2. The probability of signing a loan increases with income: it is $3.8 \%$ among eligibles for the highest subsidy, and $9.79 \%$ among non-eligibles.

\subsection{The empirical methodology}

We use two main strategies to relate incentives to borrow and actual borrowing to the event "leaving the house of parents." The first is a reduced form Probit that measures effects of changes in the cost of borrowing of eligibles on the probability of leaving the nest. The second strategy uses a bivariate Probit to estimate the causal link between the event "getting a loan" and the event "establishing a new household". ${ }^{22}$

\subsubsection{Probit}

The first specification exploits only the IE employment survey, and is a reducedform model that determines whether changes in incentives to borrow caused by the 1999 reform and 2002 cancellation of the CB program affected the probability of leaving the house of parents.

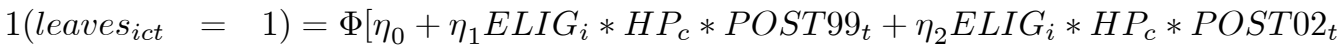

$$
\begin{aligned}
& +\eta_{3} \text { ELIG }_{i} * H P_{c}+\eta_{4} E L I G_{i} * P O S T 99_{t}+\eta_{5} E L I G_{i} * P O S T 02_{t} \\
& +\eta_{6} \mathrm{HP}_{c} * \text { POST } 99_{t}+\eta_{7} H P_{c} * \mathrm{POST}_{2} 2_{t}+\eta_{8} H P_{c}+
\end{aligned}
$$

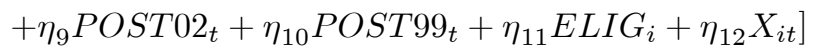

The dependent variable takes value one if the young adult leaves the house of the parents and zero otherwise. $\Phi$ is the cumulative normal function. Subscript $i$ indexes individuals, $c$ counties, and $t$ time. $E L I G_{i}$ is a binary variable indicating

activity in the real estate market was limited). We have also experimented with the whole sample, using measures of high- and low- prices in 2001 (but not of differential inflation across counties between 1998 and 2001) and the results were rather similar.

${ }^{22}$ One could also directly estimate the relationship between the event "leaving the house of the parents" and "getting a mortgage", without controlling for endogeneity. Nevertheless, three facts led us not to present those results. First, we lack of information on variables that banks use to screen their customers, but know that young adults who succesfully get a loan usually have higher and more secure streams of income and assets than those who do not. Second, individuals with a higher taste for independence may accumulate more savings prior to leave the nest, in order to meet the down payment and be able to get the loan. (Chiuri and Jappelli, 2003 or Guiso and Jappelli, 2002). Third, even if every individual had access to the amount of mortgage debt he or she wanted, we do not observe each young adult's perception of his or her future income stream. Young adults may decide to delay nest-leaving until they feel they have a secure income stream they feel they can draw on (Becker et al., 2004, JuradoGuerrero, 1999), and the subjective perception of the secureness of an income stream is not usually reported in survey data. In sum, a simple regression of the event "leaving parental home" on the variable "getting a loan" may confound access to credit with the influence of many other variables. These problems lead us to exploit the variation in changes in of access to loans associated to fluctuations in the price of credit induced by policy reforms. 
whether or not the individual is eligible for some type of subsidy. ${ }^{23}$ The omitted group includes individuals who are not eligible for the CB program. POST $99_{t}$ is a binary variable that only takes value 1 if the observation belongs to the periods of 2000 and 2001. POST02 $t$ is a binary variable that takes value 1 if the observation belongs to the post-cancellation periods of 2003 and the first three quarters in 2004. We decided to drop year 2002 from the analysis because it was hard to establish in which specific quarter the CB program ceased to operate. $H P_{c}$ is a dummy variable that takes value 1 if the (quality unadjusted) average price of the squared meter of housing in the county of residence in 1998 was above the country-wide median.

The parameters of interest in model (1) are $\eta_{1}$ and $\eta_{2}$, the coefficients of the interaction between the time dummies, the eligibility dummies and the dummy of high-price county of residence. The interpretation of $\eta_{1}$ is the difference between the propensity to leave the house of parents between the pre-reform and the post-reform periods among eligible individuals living in high price areas and in low price areas. From that magnitude, the corresponding estimate for non-eligibles is subtracted. If young adults responded to increased difficulty in getting loans by staying with their parents, $\eta_{1}$ would be negative. ${ }^{24}$

$\eta_{2}$ measures the difference between the change in the propensity to establish a new household during the pre-1999 reform period and the post-cancellation 2003-2004 periods for eligibles and the corresponding change for non-eligibles. We expect $\eta_{2}$ to be zero; the relative favoured access to borrowing for eligible individuals in low price areas that the ceiling created during the period spanning 2000-2001 should have disappeared after the cancellation. ${ }^{25}$

Specification (1) attributes to the change in incentives following the 1999 reform any time trend that affected negatively the probability of establishing a new household between 1998 and 2001 among eligible individuals in high-price areas relative to eligibles in low-price areas, and that was not present among non-eligible young adults. Thus, specification (1) erroneously identifies as an effect of the program any other variable that correlates with such trend (like, say an increase in banking competition in cities). We use the 2002 cancellation as a way of testing whether time trends that affected eligibles in high price areas are driving out results. The 2002 cancellation of the CB program caused a larger disincentive to eligible individuals in low-price areas than to eligible adults in high-price areas. Thus, testing whether or not $\eta_{2}$ equals $\eta_{1}$, and whether or

\footnotetext{
${ }^{23}$ For exposition purposes, we group all eligible individuals together in the description of the methodology. In the empirical analysis below, we allow for different effects for individuals who could apply for the $24 \%, 16 \%$ and $8 \%$ subsidies. We also decided to pool together eligibility groups IV and non eligibles in the empirical work. The reason is that there is a relatively small number of individuals who are not eligible, and that the eligibles for the lowest subsidy only got access to a small subsidy of $4 \%$ in the interest rate.

${ }^{24}$ In Tables 5-7, we do not report $\eta_{1}$, but the marginal effect of the interactions on the probability of leaving the nest, evaluating the rest of the variables at their sample means. We also experiment with two-stage-least squares specifications in Table 8.

${ }^{25}$ Another test of the theory would be simple differences-in-differences estimates of nestleaving among eligibles and not-eligibles using 1998 and 1999 as the "before" period and 2003 and 2004 as the "after" period. We experimented with those specifications, but the results were noisy.
} 
not $\eta_{2}$ equals zero provides a cross-check about the validity of our identification strategy.

Finally, we estimate (1) weighted Probits, where the weights reflect the inverse probability that a household stays in the sample $(5 / 6$ prior to 2003 and $4 / 5$ after 2003). In practice, the weighting made no noticeable difference on the estimates.

\subsubsection{Bivariate Probit}

The former estimation method does not deliver the relationship between getting a loan and establishing a new household. To estimate that relationship we use a bivariate Probit which allows the decisions of getting a loan and of establishing a new household to be simultaneous. This strategy is applied to the 1998-2001 waves of the employment survey IE, matched to the credit records. The exact model estimated is

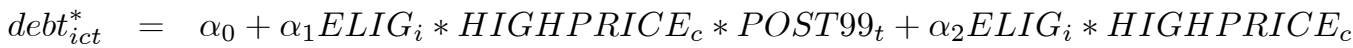

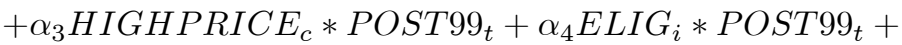

$$
\begin{aligned}
& +\alpha_{5} \text { HIGHPRICE } E_{c}+\alpha_{6} E_{L I G_{i}}+\alpha_{7} P O S T 99+\alpha_{8} X_{i t}+\varepsilon_{i c t}^{\text {debt }} \\
& \text { leave_nest } t_{i c t}^{*}=\beta_{0}+\beta_{1} \text { debt }_{i c t}+\beta_{2} E L I G_{i} * H I G H P R I C E_{c}
\end{aligned}
$$

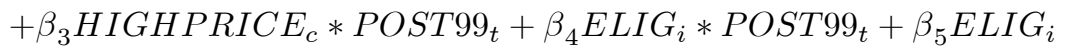

$$
\begin{aligned}
& +\beta_{6} \text { HIGHPRICE } E_{c}+\beta_{7} \text { POST } 99+\beta_{8} X_{i t}+\varepsilon_{i c t}^{\text {cores }}
\end{aligned}
$$

$d e b t_{i c t}^{*}$ and leave_nest $t_{i c t}^{*}$ are latent variables indicating the propensity to borrow and to leave the nest, respectively. debtict is an indicator of whether or not debt ${ }_{i c t}^{*}$ is positive. $\varepsilon_{i c t}^{\text {debt }}$ and $\varepsilon_{i c t}^{\text {cores }}$ are assumed to be jointly normally distributed, with unit variance and possibly nonzero correlation. Identification of the simultaneous equations system is achieved (aside from functional form) by assuming that the third-order interactions between $E L I G_{i}, H I G H P R I C E_{c}$ and POST $99_{t}$ affect the propensity of a young adult to leave the house of the parents only through their impact on the probability of accessing the mortgage market. In other words, the identification assumption is that the only event that affected differently eligible young adults living in high price and low price areas between 1998 and 2001 was the 1999 reform of the CB program, and that the reform affected nest-leaving only through changes in borrowing behavior.

The parameter of interest is the average difference between the probability that a young adult leaves the house of the parents if he or she gets a loan and the probability of leaves if he or she does not. We compute that parameter by estimating for each sample member the difference between the probability of leaving the nest if the young adult got a loan (setting debt $t_{i c t}$ to 1 in $2 \mathrm{~b}$ ) and the same probability setting debtict to zero in $2 \mathrm{~b}$. The sample mean of those 
differences is what we call the average treatment effect of getting a loan on leaving the nest.

Finally, and to get more precise estimates we include additional covariates $X_{i t}$. Namely, we experiment with the income and education of the child and with the income and age of the parent. If children have a taste for independence, children with higher income levels should be less likely to coreside (Rosenzweig and Wolpin, 1993). The impact of the education of the child is ambiguous. While young adults with higher potential earnings should be more likely to establish their own household, these adults have had less time to earn and save towards meeting a down payment requirement. Parental income should increase the chances of living with parents if consumption in parental home as a public good component. ${ }^{26}$ Finally, some specifications include 14 district dummies intended to capture the combined effect of regional labor markets and of housing prices in the area. ${ }^{27}$

\section{Results}

We present our results in four steps. The first is to illustrate the source of variation behind the estimates of model (1) by comparing the mean probability of establishing a new household by eligibility group, period and time. The second step is to document how the 1999 reform affected the borrowing behavior of young adults. The third step is to estimate model (1). Finally, we estimate the relationship between getting a loan and leaving the nest using models (2a) and $(2 \mathrm{~b})$.

\subsection{Triple-differences evidence}

Table 3 illustrates the source of variation that underlies the estimates of model (1). That exercise groups together eligible individuals for the three highest subsidies. Due to limited sizes in some cells of non-eligibles, we consider eligibles for the lowest subsidy as non-eligibles. Those individuals had access to a very low subsidy (4\%, according to our estimates), and their average income and age was similar to those of non-eligibles. ${ }^{28}$ The top panel in Table 3 compares the change in the probability of leaving the house of the parents among young individuals eligible for the maximum three subsidies living in high price areas.

\footnotetext{
${ }^{26}$ If young adults have bargaining power in the household of the parent, they will benefit from higher consumption if they stay with wealthier parents than if they establish a new household. The reason is that independent children only benefit from higher parental income if parents decide to give them interhousehold transfers (Diaz and Guillo, 2001, or Becker et al, 2004).

${ }^{27}$ The districts we include are Aveiro, Beja, Braga, Evora, Faro, Vila Real, Coimbra, Leiria, Castelo Branco, Santarem, Lisboa, Porto, Portalegre, Setúbal and Viseu. We included neither the islands, or data from Guarda or Bragança, with limited borrowing activity. The reference district is Lisbon.

${ }^{28}$ Including eligibles for the lowest subsidy as a treatment group does not change the estimates much, but it increases the standard errors, given that some cells in Tables 3 and 4 contain relatively few observations.
} 
The bottom panel shows the evolution of the propensity to coreside among our control group: non-eligible young adults and eligibles for the lowest subsidy. Row 1, columns 1 and 2 in Table 3 show that the probability of leaving the nest among eligible individuals in high-price areas fell from 2.41 percent in 1998 to 1.98 percent in the period spanning 2000-2001. That relative drop in the propensity to live with parents did not happen among eligibles living in low price areas, for whom the probability of leaving the nest increased slightly: from 2.10 percent in the pre-reform period to 2.31 percent in the post-99 reform period. Thus, the difference between the growth of the probability of leaving among eligible individuals in high price areas (-.43 percent, in column 3, row 1 of Table 3 ) and the corresponding difference among individuals in low-price areas $(.21$ percent) amounted to .63 percent (standard error: .385). That is the differencein-difference estimator of the impact of the 1999 reform on the probability of leaving the nest, shown in column 3, row 3 of Table 3 . Note that differential trend is unlikely to be associated to a special trend in high-price areas. Rows 5 and 6 show the same trends, but among non-eligible young adults and for the group of individuals in high-price areas, the probability of leaving the nest actually increased after 1999. ${ }^{29}$ The difference-in-difference estimate for that group is 2.08 percentage points (Table 3, column 3, row 7). The triple difference estimator is obtained subtracting from the difference-in-difference estimate for eligible individuals the corresponding estimate for non-eligible individuals, and amounts to -.0271 percentage points (standard error: .135), shown in Table 3, row 4, column 3. That estimator suggests that the 1999 reform did have an impact on the probability of leaving the nest.

We turn now to the 2002 cancellation. As we mentioned in Section 2, the reason for a difference between the probability of establishing a new household in high and price regions was created by the introduction of a ceiling in the price of the house that could be bought using the program, and should have disappeared after the cancellation of the program. Table 4 checks whether or not a significant difference exists between the pre-1999 period and the after-cancellation period. Among eligible individuals in high-price areas, the probability of leaving the household of parents increased by .12 percentage points: from 2.4 percent to 2.52 percent (Table 4 , row 1 , columns 1 and 2 ). The corresponding increase in low-price areas was .42 percent (Table 4, row 2, column 3). The difference is -.0031 (standard error: .04), shown in Table 4, column 3, row 3. The magnitude of the DD estimate of the 2002 cancellation on eligible in high price areas, relative to the pre-reform period is half the comparable DD estimate of the 1999 reform: .0063, shown in Table 3, column 3, row 3.

Finally, the bottom panel of Table 4 shows the corresponding estimates among non-eligible individuals. The evolution of the propensity to leave the nest for non-eligibles in high- and low- price areas is somewhat noisy, but also points to differences that are not statistically different from zero.

\footnotetext{
${ }^{29}$ One can argue that the 1999 reform should have not affected the patterns of nest-leaving between non-eligibles in low- and high-price regions, but we find a positive effect. To explore the sensitivity of the results to that impact on a placebo group, we present below estimates that only use the variation in nest-leaving within eligible individuals.
} 
The DDD estimates in Tables 3 and 4 suggest then that between 1998 and 2002 the relative probability of establishing a new household fell in those areas in which eligible individuals had most difficult access to a subsidized loan, while it did not for the group that was not eligible for the subsidy. Second, once the ceiling was removed by the cancellation of the program, the relative difference between the propensity to establish a new household among eligible individuals in high- and low- price areas disappeared. We attribute those results to the 1999 reform and 2002 cancellation of the CB program.

\subsection{The impact of the 1999 reform on borrowing}

We start by examining whether or not the changes reported in Table 3 had their correlate in access to the credit market. We use the matched IE-CRC dataset, whose descriptive statistics are shown in the second panel of Table 2. As we only have contemporaneous information on income, debt and demographics between 1998 and 2001 the exercise in this subsection exploits only the 1999 reform.

Our estimation strategy amounts to implementing equation (1), but now using as the dependent variable a binary indicator that takes value 1 if the individual signed a loan during the first quarter of 1997 and the first quarter of 1999 (for observations pre-reform) or between 2000 and 2002 (for observations post-reform). Otherwise, the indicator is zero. As the key covariates eligibility and location only vary across individuals, but not within individuals, the sample we use contains one observation per young adult and reform period. That is, if we observe the individual in several quarters, but all of them before (after) the first quarter of 2000 , we only use one observation of that individual. Those individuals whom we observe before and after the reform, we include two observations: one pre-reform and the other post-reform.

The specification we run is exactly the same as in model (1), but with the dependent variable being an indicator of having acquired "market debt" between 1997 and 1999 (pre-reform) and between 2000 and 2002 (post-reform). Table 5 includes four specifications. The first model only contains as covariates the interaction terms described in the methodology subsection, a second-order polynomial of the deviation of age minus 25 and gender. The second model adds the logarithm of income of the young adult. The third model adds family size and educational intercepts as covariates (namely, a dummy of completion of 6th grade or less and another of completion of at least high school). The last column adds parental characteristics, like income and age. The standard errors (in parentheses) are corrected for heteroscedasticity and arbitrary correlation between the observations of the same individual.

The coefficients of interest in Table 5 are the interaction between county of residence, eligibility class and the post-99 reform indicator. Our estimate of the impact of the ceiling on the borrowing behavior of eligible individuals in high price areas is -.040 (standard error: .09), shown in Table 5, row 1, column 1. Thus, after the 1999 reform, the probability of signing a loan among eligible individuals in high price regions fell by 4 percentage points. The coefficient of the impact of the 1999 reform on the second eligible group (who could lose a $16 \%$ 
subsidy) is -.032 (standard error: .004). Finally, the coefficient for the group eligible for the third subsidy is -.023, smaller than for the rest of the groups, and imprecisely estimated. Introducing other covariates does not alter the results.

Table 5 confirms that the introduction of a ceiling in 1999 coincided with a fall in access to the mortgage market of those groups that were most likely to be affected by the change: eligible individuals living in high price areas.

\subsection{Reduced form estimates of the probability of estab- lishing a new household}

Table 6 presents the estimates of the coefficients of model (1). The dependent variable takes value 1 if the young adult is not part of the household in the following quarter, and zero otherwise. The estimation method is a Probit model, and the reported estimates are the marginal impact on the probability of leaving the house of the parents of changes in the program, holding the rest of the variables at their sample means. The standard errors are corrected for heteroscedasticity and arbitrary correlation among observations belonging to the same individual.

The coefficients of interest are the triple-order interactions between the eligibility, time dummies and dummies of residence in a county that was low-price before the 1999 reform. The impact of the 1999 reform on young adults who are eligible for the subsidy and live in high price areas is measured by $E L I G_{i}$, $\mathrm{POST}_{\mathrm{O}} \mathrm{g}_{t}$ and $\mathrm{HIGHPRICE_{c }}$, and should be negative if nest-leaving responds positively to the price of mortgage debt. Conversely, the interactions between $E_{L I G} \mathrm{POST}_{2} 2_{t}$ and HIGHPRICE $E_{c}$ should be zero.

The specification in the first column of Table 6 contains a second order polynomial of the age of the child minus 25 and gender as covariates. The second adds the deviation of log-income of the young adult from the sample mean, and the deviation of the age of the parent from 57 . The last column also adds education of the child and parental income.

The estimate of the interaction between ELIG_ $1_{i}, P O S T 99_{t}$ and $H I G H P R I C E_{c}$ in column 1 , row 1 of Table 6 is negative and significantly different from zero: -.018 (standard error: .006). That means that among eligibles for the $24 \%$ subsidy, the proportion of young adults leaving the nest decreased by $1.8 \%$ after the 1999 reform. The coefficient of the interaction between $E L I G{ }_{2} 2_{i}, P O S T 99_{t}$ and $H I G H P R I C E_{c}$ is strikingly similar in absolute value: -.016 (standard error: .006). Eligible individuals for the second subsidy had a lower subsidy, a fact that suggests that the response of living arrangements to incentives to access credit markets is not constant over the income distribution. Finally, the estimate of the impact of the 1999 reform on the probability of leaving the nest for the third eligible group $\left(E L I G_{-} 3_{i}, H I G H\right.$ PRICE $E_{c}$ and $\left.P O S T 99_{t}\right)$ is also negative. The magnitude is -.018 , and the standard error is .007. Nevertheless, the latent index Probit coefficient (not shown) is very imprecise in that case.

Rows 4 through 6 of Table 6 (column 1) present the impact of the 2002 cancellation on the probability of living with parents. The estimate of the interaction between ELIG_ $1_{i}, P O S T 02_{t}$ and $H I G H P R I C E_{c}$, shown in row 4, 
column 1 of Table 6, is .004 (standard error: .013) positive, but not significantly different from zero. The coefficient of the interaction between $E L I G{ }_{2}{ }_{i}$, $\mathrm{POST}_{0} 2_{t}$ and HIGHPRICE$E_{c}$ is also positive, but less precise: .008 (standard error: .023). Finally, the gap between the propensity to leave the nest in high- and low- price areas was also negative for the third eligible group. Row 6 in Table 6 shows that the estimate for the corresponding interaction between ELIG $3_{i}, \mathrm{POST}_{2} 2_{t}$ and HIGHPRICE $E_{c}$ is -.002 (standard error: .022).

We have tested if the estimates of the interaction terms $E L I G_{i} * P O S T 99_{t} *$ $H I G H P R I C E_{c}$ and $E L I G_{i} * P O S T 02_{t} * H I G H P R I C E_{c}$ in the latent index specification in column 1 of Table 6 are significantly different from each other. The difference between the interactions for the group eligible for the highest subsidy is significantly different from zero at the $3 \%$ confidence level. The differences for the second and third group are different from zero at the $6.7 \%$ and $32 \%$ confidence level, respectively. Thus, the data support the hypothesis that, at least for individuals who were eligible for the highest two subsidies, the differential trend between eligibles in high- and low- price regions disappeared after 2003. The evidence for the third group is less clear-cut. Due to the imprecision of the estimates, we cannot reject the null of absence of a break of the trend in nest-leaving between high- and low-price areas for eligibles for the $8 \%$ subsidy.

Columns (2) and (3) introduce other covariates, like the income of the child (column 2), and the parent (column 3) without noticeable impact on the results. Our interpretation of the results is that the 1999 reform introduced a gap in the probability of leaving the home of parents among eligible individuals in highand low- price areas of about 1.8 percentage points. At least for the two groups with the highest subsidies, that gap disappeared after 2002. We attribute those trends to the 1999 reform and the 2002 cancellation of the CB program.

\subsection{Access to credit markets and nest-leaving}

This subsection builds on the estimates on the previous two sections to quantify the impact of access to credit markets on the probability of establishing a new household. Selected estimates of the bivariate probit are shown in Table 7 (see Appendix Table A.1 for the full listing of estimates). As in previous tables, we introduce covariates sequentially, and start with the simplest specification. Column 1 contains a model in which the only covariates in both equations are, aside from the interactions of eligibility, location and time, a second order polynomial of the deviation of age from 25 and an indicator of whether the young adult is a female.

Rows 1 through 3 in the first column of Table 7 (Panel A) report estimates of the impact of the triple interactions between eligibility, location and time on the probability of getting a loan using a bivariate Probit model. The estimate of the interaction ELIG_1 $1_{i}, H I G H P R I C E_{c}$ and POST $99_{t}$ in the loan equation is .617 (standard error: .325). The corresponding estimate for young adults eligible for the second highest subsidy is -.841 (standard error: .462). The first estimate is significantly different from zero at the 5.8 per cent confidence level, and the 
second at the 6.9 per cent. Row 1, column 1 in Panel B of Table 7 presents the estimate of the latent index coefficient of the probability of getting a loan on leaving the nest. The estimate is .824 (standard error: .448), significantly different from zero at the 6.6 percent confidence level.

The average treatment effect estimate is shown in Table 7, Panel B, column 1 , row 7 , and is .089 . It suggests that getting a loan increases the probability of leaving the nest in a quarter by 8.9 percentage points. The corresponding estimate in yearly terms is reported in row 8, column 1 of Panel B in Table $7 .{ }^{30}$ Getting a loan increases the chances of nest-leaving by 33 percentage points a year.

Columns (2) through (5) include sequentially the income of the young adult in both the selection and outcome equation, education, demographics of the parent and location dummies. The estimates of interest in the selection and outcome equation become more precise, and our preferred estimate is in the column 3 of Table 7 , that shows an impact of getting a loan on establishing a new household of 34.8 percentage points (row 8, Panel B, column3 of Table 7). The impact of getting a loan on the probability of establishing a new household fluctuates between 31 and 51 percentage points. ${ }^{31},{ }^{32}$

\subsubsection{Robustness checks}

Behavior of non-eligibles: A concern with the estimates in Table 7 may arise when one examines the triple difference estimates presented in Tables 3 and 4. A large share of the triple differences estimate in Table $3(-.027)$ is due to the

\footnotetext{
${ }^{30}$ We make use of the following formula. We denote by $P_{\text {leave }}$ the unconditional probability of "leaving the nest" in a quarter. $P_{\text {stay }}=1-P_{\text {leave }}$ is the corresponding probability of staying with parents. The impact of getting a loan on the probability of leaving home is $\frac{d P_{\text {leave }}}{\text { dloan }}$ The probability of leaving the nest in a year is computed as the sum of the probabilities in each quarter of the year:

$$
\begin{aligned}
& P_{\text {leave }}+P_{\text {stay }} P_{\text {leave }}+\left(P_{\text {stay }}\right)^{2} P_{\text {leave }}+ \\
& \left(P_{\text {stay }}\right)^{3} P_{\text {leave }}
\end{aligned}
$$

Differentiating the previous expression, and rearranging, we obtain the impact of getting a loan on the probability of leaving parental home in any quarter of the year as

$$
\begin{aligned}
& \frac{d P_{\text {leave }}}{d \text { loan }}\left[1+P_{\text {stay }}+\left(P_{\text {stay }}\right)^{2}+\left(P_{\text {stay }}\right)^{3}\right]- \\
& P_{\text {leave }}\left[1+2 P_{\text {stay }}+3\left(P_{\text {stay }}\right)^{2}\right] \frac{d P_{\text {leave }}}{d \text { loan }}
\end{aligned}
$$

The estimates in row 8 in Table 7 are obtained by substituting $\frac{d P_{\text {leave }}}{d l o a n}$ by the corresponding estimate in row $7, P_{\text {stay }}$ by .972 and $P_{\text {leave }}$ by .022 .

${ }^{31}$ We bootstrapped the ATE coefficient to obtain standard errors, but obtained asymetric distributions. We conducted tests of differences from zero using confidence intervals based on 1,000 replications, and obtained that ATE coefficients were different from zero at the 6-7 percent confidence level.

${ }^{32}$ The correlation between the unobservable variables is negative in all specifications. While we do not place much emphasis on those findings, one can interpret that a negative sign indicates that many individuals with a high propensity to establish their own household are unlikely to obtain credit. Such finding is consistent with the notion that young adults defer nest-leaving because of limited access to debt.
} 
behavior of non-eligibles who, in principle should be a placebo group, unaffected by the reform (the DD for this placebo group is -.0208, see Table 3, Panel B). To assess if our results are merely driven by the behavior of non-eligibles, we ran another specification in which we exclude non-eligibles. The effect of getting a loan on the probability of living with parents is still identified by the variation across counties in the pre-reform price of housing (i.e., the variation used in the DD estimate among eligibles, shown in Panel A of Table 3, column 3, row 2). We estimated a bivariate probit using the sample of eligibles, in which we assume that the interaction between $H I G H P R I C E_{c}$ and $P O S T 99_{t}$ affects nest-leaving decisions only through its effect on the credit market. The result is shown in the first column, Panel B of Table 8 and is .47 (row 3), within the range of estimates in Table 7. That finding reassures us that our estimates are indeed driven by the behavior of eligible young adults.

Alternative minimum age Another concern with the range of ages used in the analysis is that 18 may be too low an age cut-off. Table 8, column (2) present results with alternative age cut-off of 23 (after college decisions have been made). The point estimate of the causal impact of the getting a loan on leaving the nest is 0.46 (Table 8 , row 3, column 2 of Panel B), similar to the previous estimates, but less precise.

Gender Column (3) does the analysis only for males. It is well known that females leave home before males do (Billari et al., 2001). The results shown in row 3, columns (3) and (4), Panel B of Table 8 suggest that the magnitude of the effect estimated in Table 7 is due to the behavior of males (who are also more likely to borrow). The Portuguese is a very traditional society, and establishing a new household and getting married are very correlated events. The evidence in columns (3) and (4) suggests that the decision to establish a new household depends much more on the economic situation of the future husband than on the future wife's (Manacorda and Moretti also find that boys' decisions of leaving the nest react more to parental earnings than girls').

Alternative functional form: The column 5 in Table 8 presents alternative estimates of the relationship between access to mortgage loans and credit formation using a two stage least squares estimator (TSLS). TSLS estimates do not rely on assumptions about the distribution function of unobservables $\varepsilon_{i c t}^{\text {coresid }}$ and $\varepsilon_{i c t}^{d e b t}$ to identify the parameter of interest. As in the bivariate Probit specification, the impact of getting a loan on the probability of establishing a new household is identified with the triple interaction between eligibility, post-reform and high price dummies, but we let all the lower-level interactions affect the propensity to leave the nest. Column 5, row 3 in Panel B of Table 8 presents the TSLS estimate of the impact of getting a loan on establishing a household using a specification otherwise identical to that used in Column 2, Table 7. The quarterly estimate, shown in row 3 is somewhat larger and more imprecise than the bivariate Probit case: 144 (standard error: .080). The estimate yearly implies that getting a loan over the last two years increases the probability of leaving the parental nest by .539 percentage points.

Finally, column (6) uses a TSLS model to examine if the probability of leaving the nest responds to the amount borrowed (in thousand euro), where the 
amount borrowed is zero for non-borrowers. The results in Column (6) suggest that an average increase in the amount borrowed by 10,000 euro (mixing both the extensive and intensive margins) increases the probability of leaving the nest in a year by 16 percentage points.

General equilibrium effects: the behavior of real estate prices The 1999 reform should have caused non trivial effects on the prices of real estate. On one hand, prices of houses below the ceiling should have increased if eligible individuals chose to buy a cheap house to qualify for the program. Such forces should not operate for houses above the ceiling. Hence, one may worry that the CB program caused a compression in the distribution of the price of the houses. In that case, the estimates in Table 3 and 7 would estimate the impact of a relative increase in housing prices, rather than the impact of a change in the interest rate.

In Martins and Villanueva (2005), we estimated the impact of the 1999 reform on the prices of real estate in two different ways. First, we tested whether or not the 1999 reform compressed the distribution of real estate prices across counties by regressing the 2001 within-county dispersion between the 50th and 25 th centiles of the housing price distribution on the fraction of eligibles in a county. We found little evidence for compression. Second, we used differencesin-differences to test whether or not the 2002 removal of the ceiling increased the dispersion in the distribution of real estate prices. Again, we found little evidence of increased dispersion in housing prices after 2002. We interpret those results as evidence that the impact of the 1999 and 2002 reforms on the probability of living with parents occur through the channel of mortgage use, rather than through housing prices.

Anticipation effects: Did individuals react to announcements of changes the program anticipating their borrowing behavior?. ${ }^{33}$ The 1998 was discussed in the press, and there could be some anticipation effects, as there was a peak in borrowing in 1999. We have not used the borrowing data from 1999 to avoid such effects. Second, we have tested for pre-reform differential trends in borrowing between 1997 and 1998, and failed to detect a relative increase in borrowing among the treated group (eligible young adults in high price areas). Finally, the 2002 cancellation was included with a package of measures reducing public debt, and we are less sure about anticipation effects in that case.

\section{The magnitude of the estimate}

Comparison with the literature: At face value, the estimates in Tables 7 and 8 are large. Our preferred estimates (Table 7, row 8, column 3) imply that obtaining a loan increases the probability of establishing a new household by 34 percentage points. We briefly review comparable estimates in the literature. A possible benchmark are estimates of the impact of the Veteran Administration's program on home ownership, in the United States. The VA program relaxed liquidity constraints by reducing the size of the down payment required to purchase a

${ }^{33}$ We think that anticipating effective nest-leaving is less likely 
house. Among other findings, Vigdor (forthcoming) documents that relaxation of the borrowing for veterans increased the proportion of home-owners by 7 percentage points (Vigdor looks at the stock of home-owners, rather than at the flow). Our results are also consistent with Chiuri and Jappelli (2003) who use European-wide micro data and document that improvements in countrywide indicators of limited access to mortgage debt have decreased the age at which individuals get access to their first home. Nevertheless, one must take into account that both Vigdor and Chiuri and Jappelli (2003) focus on already established households and take the decision of establishing a new household as exogenous. ${ }^{34}$

Counterfactual: Another possibility to put our estimate in context is to use our estimates to perform a counterfactual simulation. Assume that the estimates in Tables 7 and 8 are response of establishing a new household to the availability of a new loan in any European country. Then, one could answer the question: how much of the dispersion in the rates of nest leaving in Northern and Southern Europe can be explained by the differences in access to mortgage debt documented in Table 1 ?

We use the sample described in Section 2. Namely, young adults from 10 European countries born between 1958 and 1976, and who, are the time of the 1994 survey were living with their parents. ${ }^{35}$ We then track in which year young adults move to a new household in which none of the members are ascendants of the respondent. We estimate the following linear probability model.

$$
\begin{aligned}
1(\text { LEAVE }= & 1 \mid \text { age, country })=\alpha_{0}+\sum_{i=1}^{i=9} \alpha_{i} \text { COUNTRY } Y_{i} \\
& +\beta_{1}\left(\text { age }_{i}-25\right)+\beta_{2}\left(a g e_{i}-25\right)^{2}+u_{i t}
\end{aligned}
$$

The country-specific fixed effects $\alpha_{1}, \ldots, \alpha_{9}$ are country-specific intercepts estimating the difference between the probability of leaving the nest of a 25 year-old adult in the particular country and Belgium. Model (4) includes an indicator of having borrowed:

$$
\begin{aligned}
1(\text { LEAVE }= & 1 \mid \text { age }, \text { country })=\delta_{0}+\delta_{1} 1\left(\text { LOAN>0)+ } \sum_{i=1}^{i=9} \gamma_{i} \operatorname{COUNTRY}_{i}\right. \\
& +\beta_{1}\left(\text { age }_{i}-25\right)+\beta_{2}\left(\text { age }_{i}-25\right)^{2}+u_{i t}^{1}
\end{aligned}
$$

\footnotetext{
${ }^{34}$ Other literature has examined the relationship between renting and the probability of cohabiting with parents. Börsch-Supan (1986) estimates that the steady state proportion of young individuals who are not heads would fall by between 23 and 32 points in the US as a response to the implicit subsidies in a experimental housing allowance program. Haurin et al. (1993) find that doubling the rents would increase the average age of home leaving by 2 years.

${ }^{35}$ We decided to drop Greece from the results because we did not trust much our computations of the summary statistics and attrition rates. The estimates are not affected by that omission.
} 
where $\delta_{1}$ is constrained to be one of our estimates of the impact of access to mortgage debt on "leaving the nest". To assess the role of access to the borrowing market on the probability of leaving the nest, we compare the dispersion of the estimated country dummies $\alpha_{i}$ in model (3) with the dispersion of the country dummies $\gamma_{i}$ in model (4). We attribute to differences in access to credit markets any fall in the variance of the distribution of the country dummies.

Table 9 shows the estimates of models (3) and (4). The first column shows estimates of the unrestricted model (3). The second model shows the constrained regression model, assuming that $\delta_{1}$ equals .34 (Table 7, Panel B, row 8, column $3)$. Introducing the restriction reduces the variance of the country dummies from .0039 (Table 9, Panel B, column 1) to .00339 (Table 9, Panel B, column $2)$. That is, the variance of country dummies falls by $16 \%\left(=1-\frac{.00339}{.0039}\right) * 100$. We have also experimented using the larger estimate of .54 - Table 8, Panel $\mathrm{B}$, row 7, column 5. The corresponding reduction in the variance of country dummies is $20 \%\left(=1-\frac{.00312}{.0039}\right) * 100$.

Those estimates require strong assumptions that must be borne in mind. First, we assume that the estimates in Table 7 and 8 apply to the rest of European countries. That assumption can fail if the relationship interacts with other country-specific characteristics, like the absence of well-developed rental markets, or different labor markets for the young. Second, the data on the ECHP is specific about mortgage debt, while the data in the matched IE-CRC sample refers to all debt with maturity longer than the year. Still, our crude estimates suggest that credit markets may play a substantial role in explaining cohabitation patterns.

Interpretation. How can an economy have at the same time a limited use of debt markets and a large behavioral response of debt and household structure to changes in interest rates? In other words, why do not private banks exploit that potential demand for debt? A serious theoretical modelling of such outcome is beyond the scope of this paper, but we would like to sketch a possible explanation. Section 2 documents that repossession costs if the borrower chooses not to repay debt are large in Southern Europe. In a world in which banks make zero profits on each loan on average, and face uncertainty about whether or not the borrower will repay costs, lenders may optimally charge high interest rates per loan in order to absorb large losses involved with a customer bankruptcy. High interest rates, a low use of mortgage debt, and a large response of debt to interest rates can then coexist.

\section{Conclusions}

This paper has used a dataset with administrative records of individual debt and survey information on household structure to estimate the causal link between accessing credit markets and establishing a new household. To identify plausibly exogenous changes in the access to credit markets, we exploit the reform and subsequent cancellation of a program in Portugal that provided interest relief at source on mortgage loans signed by low- and medium-income young adults. 
We document two main findings. The first is that access to a mortgage loan increases the probability that a young adult "leaves the nest" by between 31 and 54 percentage points. Combining our preferred estimates with crosscountry data containing the use of mortgage debt and household structure, we find that differences in the availability of credit can explain up to $20 \%$ of the cross-European variance of nest leaving. Our results also suggest that young adults insure against fluctuations in the cost to mortgage debt by delaying their decision to establish a new household.

We would like to flag two lines for further research. The first is to exploit recent developments of credit markets in Eastern and Southern Europe to estimate the link between access to credit markets and several outcomes of young adults like marriage, fecundity and the quality of job matches. The second line of research is to study what specific types of credit market limitations account for the limited access to debt markets among Southern European young adults.

\subsection{References}

Aasve, A., Burgess, S., Chesher, A., Propper, C. (2002) "Transition from Home to Marriage of Young Americans". Journal of Applied Econometrics (17): 1-23.

Alessie, R., A. Brugiavini, and G. Weber (2005) "Saving and Cohabitation: The Economic Consequences of Living with One's Parents in Italy and the Netherlands" NBER Working paper no. 11079.

Becker, S. Bentolila, B., Fernandes, A. and Ichino, A. (2004) "Job Insecurity and Children's Emancipation", mimeograph, CEMFI.

Billari, F.C., Philipov, D. and Baizán, P., (2001), "Leaving Home in Europe: the Experience of Cohorts Born Around 1960" International Journal of Population Geography 7(5): 339-356.

Blanchard, O. and P. Portugal (2001) "What Hides Behind an Unemployment Rate? Comparing Portuguese and US Labor Markets" American Economic Review 91.

Bover, O. (2005) "La Situación Patrimonial de las Familias Españolas: Una Comparación Microeconómica con Estados Unidos, Italia y el Reino Unido." Bank of Spain Economic Bulletin no 113. April.

Börsch-Supan, A. (1986) "Household Formation, Housing Prices and Public Policy Impacts." Journal of Public Economics 25: 145-164.

Cameron, S. and Taber, C. (2004) "Estimation of Borrowing Constraints Using Returns to Schooling" Journal of Political Economy 112: 132-138.

Card, D.; and Lemieux T. (2000) "Adapting to Circumstances: The Evolution of Work, School, and Living Arrangements Among North American Youth." in Youth Employment and Joblessness in Advanced Countries, edited by Richard Freeman and David Blanchflower. Chicago: University of Chicago Press.

Carneiro, P., and Heckman, J. (2002) "The Evidence on Credit Constraints in Post-Secondary Schooling" Economic Journal Vol 112: 705-734.

Chiuri M., and Jappelli, T. (2003) "Financial Market Imperfections and Homeownership: a Comparative Study" European Economic Review, vol. 47, 857-875. 
Del Boca, D. and Lusardi, A. (2003) "Credit Market Constraints and Labor Market Decisions" Labour Economics 10: 681-703.

Diaz, A. and Guilló, D. (2005) "Family Ties and Labor Supply" Investigaciones Economicas 29:2.

Ermish J., and Di Salvo, P. (1997) "The Economic Determinants of Household Formation" Economica

Fogli, A. (2004) "Endogenous Labor Market Rigidities and Family Ties" mimeograph, New York University.

Giuliano, P. (2004) "On the determinants of Living Arrangements in Western Europe: Does Cultural Origin Matter?" mimeograph, IMF.

Gonzalez-Luna, L. (2005) "Single Mothers in Europe: A Decomposition Approach" mimeograph, Universitat Pompeu Fabra

Guiso, L. and Jappelli, T. (2002) "Private Transfers, Borrowing Constraints and the Time of Home Ownership" Journal of Money, Credit and Banking vol. 34, 315-39.

Güell, M., and Petrongolo, B. (forthcoming) "How binding are legal limits? Transitions from temporary to permanent work in Spain" Labour Economics.

Haurin, R., Hendershott, P. and Kim, D. (1993) "The Impact of Real Wages and Rents on Household Formation" Review of Economics and Statistics 75(2): 284-293.

Henderson, V., and Ioannides, Y. (1983) "A Model of Housing Tenure Choice" American Economic Review 73 98-113.

Hurst, E. and A. Lusardi (2004) "Liquidity Constraints, Household Wealth and Entrepreneurship" Journal of Political Economy 112: 319-347.

Iacovou, M. (2001) "Leaving Home in the European Union" ISER Working Papers number 2001-18.

Jurado-Guerrero, T. (1999) "Youth in Transition: Housing, Employment, Social Policies and Families in France and Spain" Thesis read at European University Institute.

Laferrére, A. and le Blanc, D. "Gone With The Windfall: How Do Housing Allowances Affect Student Co-residence?" CESifo Economic Studies, Vol. 50 3/2004: 451-477.

Manacorda. M, and Moretti E. (forthcoming) "Intergenerational Transfers and Family Structure: Why Do Most Italian Youths Live With Their Parents?," Journal of the European Economic Association.

Martínez-Granado, M. and Ruiz-Castillo, J. (2002) "The Decisions of Spanish Youth: a Cross-Section Study," Journal of Population Economics 15, 305330 .

Martins, N, and Villanueva, E. (2005) "The Impact of Interest-Rate Subsidies on Long-term Household Debt" Netherlands Central Bank Working Paper no. 26, forthcoming in Journal of Public Economics.

Martins, N, and Villanueva, E. (in press) "Credit Constraints and Family Formation" in Labour Market Adjustment in Europe, Messina, Michelacci, Turunen and Zoega, edds..

Mc Garry, K., and S. Haider (2005) "Recent Trends in Resource Sharing Among the Poor" National Bureau Economic Research, No. 11612. 
Neal, D. (1999) "The Complexity of Job Mobility Among Young Men," Journal of Labor Economics, vol. 17, pp. 237-261.

Rosenzweig, M. and K. Wolpin (1993) "Intergenerational Support and the Life-Cycle Incomes of Young Men and Their Parents: Human Capital Investments, Coresidence, and Intergenerational Financial Transfers" Journal of Labor Economics, Vol. 11 (1), Part 1: 84-112.

Rosenzweig, M. and K. Wolpin, (1994) "Parental and Public Transfers to Young Women and Their Children" The American Economic Review. Vol. 84(5):1195-1212.

Vigdor. J. (in press) "Liquidity constraints and housing prices: Theory and evidence from the VA Mortgage Program " Journal of Public Economics.

\section{Data appendix: the European Household Panel}

We have selected the panel versions for Germany (SOEP), Denmark, Netherlands, Belgium, France, United Kingdom (BHPS), Ireland, Italy, Greece, Spain and Portugal. We chose to drop Scandinavian countries and Austrian because the panel length for those countries was much shorter.

We only kept observations on individuals who were born between 1958 and 1977 and were present in the original 1994 survey as the son or daughter of one of the members of the household. The sample statistics presented in Table 1 drop all observations on children once they have left the household.

Sample sizes: With those criteria, the number of children living with their parents in 1994 were 1,463 young adults for Germany, 347 for Denmark, 710 for the Netherlands, 772 for Belgium, 1,636 for France, 780 for the United Kingdom, 2,359 for Ireland, 4,062 for Italy, 1,828 for Greece, 3,775 for Spain and 2,131 in Portugal.

Overall nest-leaving: We determine that a young "left the nest" if in wave $w$ if in wave $w$ the person is no longer present in the original household, but the parental household was interviewed both in $w$ and $w-1$. Young adults who are not re-contacted following leaving the nest are included as nest-leavers in Column 1.

To determine the housing tenure in the new household (columns 3-6 of Table 1), we restricted ourselves to young adults who move to a household where neither the father or mother and present (and are thus succesfully tracked by the ECHP). That is, young adults interviewed both in waves Column 2 shows the fraction of young adults who are succesfully tracked to their new household as a percentage of all young adults who were living with their parents in the previous year. Finally, we determine if they individual has a mortgage if among their accomodation-related expenses, respondents include the amount paid as interest rates of a mortgage loan. 
Table 1: Probability of leaving the home of parents, by country

\begin{tabular}{|c|c|c|c|c|c|c|c|}
\hline & $\begin{array}{l}\text { Fraction of young } \\
\text { who leave the nest } \\
\text { (1) }\end{array}$ & $\begin{array}{l}\text { Fraction of young } \\
\text { who leave the nest } \\
\text { and are succesfully } \\
\text { interviewed } \\
\text { (2) }\end{array}$ & \multicolumn{4}{|c|}{ Tenure status on destination household } & $\begin{array}{c}\text { \# of leavers } \\
\text { succesfully } \\
\text { interviewed } \\
(6) \\
\end{array}$ \\
\hline Germany & .110 & .085 & .12 & $83 \%$ & .81 & .07 & 619 \\
\hline Denmark & .219 & .161 & .22 & $88 \%$ & .77 & .01 & 180 \\
\hline Belgium & .112 & .080 & .18 & $93 \%$ & .75 & .07 & 286 \\
\hline France & .136 & .094 & .12 & $82 \%$ & .81 & .07 & 701 \\
\hline United Kingdom & .154 & .115 & .48 & $96 \%$ & .51 & .01 & 427 \\
\hline Ireland & .114 & .041 & .46 & $87 \%$ & .46 & .07 & 396 \\
\hline Spain & .081 & .044 & .60 & $78 \%$ & .26 & .13 & 861 \\
\hline Portugal & .065 & .050 & .52 & $69 \%$ & .246 & .26 & 625 \\
\hline \multicolumn{8}{|c|}{$\begin{array}{l}\text { 1. Source: European Community Household Panel, 1994-2001 waves (GSOEP for Germany, BHPS for UK) } \\
\text { 2. Sample of young adults who, as of } 1994, \text { were between } 18 \text { and } 35 \text { years, lived with their parents. } \\
\text { 3. Each individual contributes one observation per year while living in the household of the parents. } \\
\text { Nest leavers in column (1) are the subset who move into a new household where none of his or her parents live. } \\
\text { 5. Columns (3) through (6) are proportions of the sample of leavers succesfully interviewed (sample size in column 6), and add up to one } \\
\text { (up to rounding error) }\end{array}$} \\
\hline
\end{tabular}




\section{Table 2: Descriptive statistics of samples}

\begin{tabular}{|c|c|c|c|c|c|}
\hline Panel A: Employment sample (IE) 1998-2004 & Whole sample & Eligibles 1 & Eligibles 2 & Eligibles 3rd & Non-eligibles+4th \\
\hline \multirow[t]{2}{*}{ Young adult left the household of the parents } & .0229 & .0214 & .0275 & .0264 & .0296 \\
\hline & $(.149)$ & $(.145)$ & $.163)$ & $(.160)$ & $(.169)$ \\
\hline \multirow[t]{2}{*}{ Young adult is a female } & .440 & .434 & .39 & .462 & .512 \\
\hline & $(.496)$ & $(.495)$ & $(.488)$ & $(.498)$ & $(.499)$ \\
\hline \multirow[t]{2}{*}{ Age of young adult } & 25.36 & 24.807 & 26.92 & 27.22 & 27.99 \\
\hline & $(4.75)$ & $(4.75)$ & $(4.925)$ & $(4.09)$ & $(4.07)$ \\
\hline \multirow[t]{2}{*}{ Yearly labor earnings } & 9767 & 7631 & 12960 & 15026 & 22681 \\
\hline & $(6488)$ & $(2,194)$ & $(2007)$ & $(2232)$ & $(12731)$ \\
\hline \multirow[t]{2}{*}{ Age of parent } & 55.68 & 55.09 & 57.47 & 57.32 & 58.54 \\
\hline & ( 8.53) & (8.659) & $(7.66)$ & $(7.53)$ & $(7.52)$ \\
\hline \multirow[t]{2}{*}{ Head of parental household is female } & .20 & .203 & .20 & .1748 & .185 \\
\hline & $(.40)$ & $(.402)$ & $(.40)$ & $(.38)$ & $(.388)$ \\
\hline \multirow[t]{2}{*}{ Parent does not report earnings } & .452 & .446 & .54 & .457 & .495 \\
\hline & $(.497)$ & $(.497)$ & $(.50)$ & $(.498)$ & $(.504)$ \\
\hline \multirow[t]{2}{*}{ Earnings of the parent (includes zeroes) } & 7965 & 7062 & 9422 & 10796 & 13116 \\
\hline & $(11711)$ & $(9356)$ & $(14395)$ & $(16613)$ & (19907) \\
\hline \multirow[t]{2}{*}{ Live in a county with price above the median } & .457 & .422 & .540 & .576 & .63 \\
\hline & $(.498)$ & $(.494)$ & $(.50)$ & $(.49)$ & $(.48)$ \\
\hline \multirow[t]{2}{*}{ Years 2000-2001 } & .351 & .351 & .356 & .333 & .34 \\
\hline & $(.477)$ & $(.477)$ & $(.48)$ & $(.47)$ & $(.47)$ \\
\hline \multirow[t]{2}{*}{ Years 2003-2004 } & .279 & .276 & .283 & .33 & .301 \\
\hline & $(.448)$ & $(.447)$ & $(.45)$ & $(.47)$ & $(.458)$ \\
\hline \multirow[t]{2}{*}{ Price of squared meter } & 866.53 & 850.94 & 913.06 & 910.99 & 943 \\
\hline & $(193.83)$ & $(185)$ & $(213.13)$ & $(200.2)$ & $(218.92)$ \\
\hline Number of observations: & 35,624 & 28284 & 2466 & 1361 & 3,364 \\
\hline
\end{tabular}

1. Sample of 9,314 adults between 18 and 37 years of age and living with their parents. A young adult is assumed to leave in quarter $q$ if, conditioning on his or her original household being observed in quarters $q$ and $q+1$, the individual is not a member of the household in $q+1$.

2. Standard deviations in parentheses. ELIGIBLES $1(2,3)$ takes value 1 if the young qualifies for the highest (second highest, third higest) subsidy

3. Monetary magnitudes in current euro. The year 2002 is excluded 
Panel B: Matched employment sample (IE) -individual borrowing sample (CRC) (1998-2001).

\begin{tabular}{|c|c|c|c|c|c|}
\hline & Whole sample & Eligibles 1 & Eligibles 2 & Eligibles 3rd & Non-eligibles +4 \\
\hline \multirow{2}{*}{ Young adult left the house of his parents } & .022 & .021 & .027 & .025 & .0261 \\
\hline & $(.147)$ & $(.143)$ & $(.162)$ & $(.156)$ & $(.159)$ \\
\hline \multirow[t]{2}{*}{ Young adult got a loan in the last two years } & .048 & .038 & .071 & .097 & .0979 \\
\hline & $(.21)$ & $(.191)$ & $(.257)$ & $(.297)$ & $(.297)$ \\
\hline \multirow[t]{2}{*}{ Loan amount, if positive } & 35,614 & 36,556 & 39,665 & 44,408 & 36,947 \\
\hline & $(35,197)$ & $(36,046)$ & $(33,580)$ & $(34,620)$ & $(33,951)$ \\
\hline \multirow[t]{2}{*}{ Female } & .437 & .436 & .37 & .43 & .49 \\
\hline & $(.49)$ & $(.49)$ & $(.48)$ & $(.50)$ & $(.50)$ \\
\hline \multirow[t]{2}{*}{ Age of young adult } & 25.31 & 24.76 & 26.79 & 27.31 & 28.01 \\
\hline & $(4.76)$ & $(4.75)$ & ( 3.99$)$ & $(4.09)$ & $(4.20)$ \\
\hline \multirow[t]{2}{*}{ Yearly labor earnings } & 9290 & 7263. & 12390 & 14508 & 21696 \\
\hline & (6297) & $(2,061)$ & $(1768)$ & (2208) & ( 12721) \\
\hline \multirow[t]{2}{*}{ Not read } & .016 & .019 & .014 & .002 & .001 \\
\hline & $(.126)$ & $(.134)$ & $(.12)$ & $(.045)$ & $(.035)$ \\
\hline \multirow[t]{2}{*}{6 th grade } & .429 & .493 & .25 & .22 & .108 \\
\hline & $(.495)$ & $(.50)$ & $(.433)$ & $(.416)$ & $(.304)$ \\
\hline \multirow[t]{2}{*}{ Primary school } & .22 & .244 & .194 & .118 & .082 \\
\hline & $(.414)$ & $(.43)$ & $(.39)$ & $(.322)$ & $(.27)$ \\
\hline \multirow[t]{2}{*}{ High school or higher } & .335 & .244 & .542 & .66 & .809 \\
\hline & $(.472)$ & $(.43)$ & $(.498)$ & $(.47)$ & $(.393)$ \\
\hline \multirow[t]{2}{*}{ Age of parent } & 55.39 & 54.83 & 58 & 57.74 & 58.82 \\
\hline & $(8.66)$ & $(8.80)$ & (7.63) & $(7.35)$ & (7.69) \\
\hline \multirow[t]{2}{*}{ Family size in original household } & 4.17 & 4.24 & 3.90 & 4.05 & 384 \\
\hline & $(1.40)$ & $(1.43)$ & $(1.27)$ & $(1.42)$ & $(1.11)$ \\
\hline \multirow[t]{2}{*}{ Parental income (includes zeroes) } & 7294 & 6507 & 8668 & 9955 & 13,467 \\
\hline & $(10,895)$ & $(8733)$ & $(14326)$ & $(14325)$ & $(20,553)$ \\
\hline \multirow[t]{2}{*}{ Live in a county with price above the median } & .471 & .437 & .553 & .597 & .634 \\
\hline & $(.50)$ & $(.496)$ & $(.50)$ & $(.49)$ & $(.481)$ \\
\hline \multirow[t]{2}{*}{ Price of squared meter in county } & 872 & 856 & 926 & 920 & 961 \\
\hline & $(198)$ & $(190)$ & $(221)$ & $(220)$ & $(222)$ \\
\hline Number of observations & 24,135 & 19,238 & 1,691 & 837 & 2369 \\
\hline
\end{tabular}

1. Sample of 5,385 adults between 18 an 37 years of age, living with their parents. An individual leaves in quarter $q$ if, conditional on the original household being observed in quarters $q$ and $q+1$, the individual is not a member of the household in $q+1$.

2. Monetary magnitudes in current euro.ELIGIBLES $1(2,3)$ takes value 1 if the young qualifies for the highest (second highest, third) subsidy 
Table 3: Evolution of the probability of leaving the house of parents in a quarter, by eligibility group

\begin{tabular}{lcc}
\hline \hline & Pre-reform & Post 99 reform \\
Location / period & $1998 q 1-1999 q 4$ & $2000 q 1-2001 q 4$
\end{tabular}

Treatment group: eligible young adults

1. Price of square meter in the county above nation median.

2. Price of square meter in the county below nation median.

3. Location difference at a moment in time:

4. Relative to control group

(non-eligible young adults, row 8 columns 2 and 3 )

Control group: non-eligible young adults

5 . Price of square meter in the county above nation median.

6. Price of square meter in the county below nation median.

7. Location difference at a moment in time:
(1)

\section{.0241}

$(.002)$

.0210

(.0018)

.0031

$(.0027)$

7)

(n)

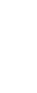

-.0032
$(.0028)$

.0198
$(.0019)$
.0231
$(.0019)$
-.0032
$(.0028)$

$2001 q 4$

Time difference

After 99 - Before 199

(3)

$-.0043$

$(.0028)$

.0021

(.0026)

D-in-D, 99 reform

$-.0063$

$(.0038)^{*}$

D-in-D-in-D, relative to pre-reform

$-.0271$

$(.0135)^{*}$

$\begin{array}{cc}.0251 & .032 \\ (.0055) & (.0062) \\ .0292 & .0153 \\ (.007) & (.0058) \\ -.0041 & .0167 \\ (.0098) & (.0085)\end{array}$

.0069

$(.008)$

$-.0139$

(.011)

D-in-D estimate, 99 reform

.0208

$(.010)^{\star *}$

1. Cells contain the proportion of young adults between 18 and 37 years of age who live with their parents when the household

is first interviewed, and leave in the following quarter. The proportion is computed by eligibility status, county of residence and period.

2. Standard errors obtained from OLS regressions, corrected by heteroscedasticity and correlation between observations at the individual level.

3. The D-in-D-in-D estimate in column 3,row 4 is obtained substracting the D-in-D estimate in row 7 , column 3 from the D-in-D estimate in row 3, column 2 


\begin{tabular}{|c|c|c|c|}
\hline Location / period & $\begin{array}{l}\text { Pre-reform } \\
\text { 1998q1-1999q4 } \\
\text { (1) }\end{array}$ & $\begin{array}{l}\text { Post-cancellation } \\
2003 q 1-2004 q 3 \\
\text { (2) }\end{array}$ & $\begin{array}{l}\text { Time difference } \\
\text { After 2002-Before } 1999 \\
\text { (3) }\end{array}$ \\
\hline \multicolumn{4}{|l|}{ Treatment group: eligible young adults } \\
\hline 1. Price of square meter in the county above nation median. & $\begin{array}{l}.0242 \\
(.002)\end{array}$ & $\begin{array}{c}.0252 \\
(.0021)\end{array}$ & $\begin{array}{c}.001 \\
(.003)\end{array}$ \\
\hline 2. Price of square meter in the county below nation median. & $\begin{array}{l}.0210 \\
(.0018)\end{array}$ & $\begin{array}{c}.0252 \\
(.0025)\end{array}$ & $\begin{array}{c}.0042 \\
(.0028)\end{array}$ \\
\hline 3. Location difference at a moment in time: & $\begin{array}{c}.0031 \\
(.0027)\end{array}$ & $\begin{array}{l}-.00003 \\
(.0033)\end{array}$ & 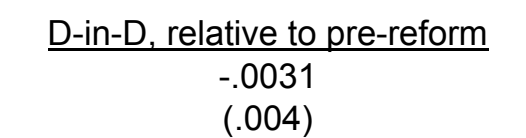 \\
\hline $\begin{array}{l}\text { 4. Relative to control group } \\
\text { (non-eligible young adults, row } 8 \text { columns } 2 \text { and } 3 \text { ) }\end{array}$ & & & 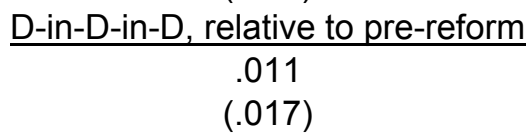 \\
\hline Control group: non-eligible young adults & & & \\
\hline 5. Price of square meter in the county above nation median. & $\begin{array}{c}.0251 \\
(.0055)\end{array}$ & $\begin{array}{c}.031 \\
(.0067)\end{array}$ & $\begin{array}{l}.006 \\
(.088)\end{array}$ \\
\hline 6. Price of square meter in the county below nation median. & $\begin{array}{l}.0292 \\
(.007)\end{array}$ & $\begin{array}{l}.050 \\
(.011)\end{array}$ & $\begin{array}{l}.0201 \\
(.014)\end{array}$ \\
\hline 7. Location difference at a moment in time: & $\begin{array}{l}-.0041 \\
(.0098)\end{array}$ & $\begin{array}{l}-.019 \\
(.013)\end{array}$ & $\begin{array}{c}\text { D-in-D, relative to pre-reform } \\
-.014 \\
(.0167) \\
\end{array}$ \\
\hline
\end{tabular}

1. Cells contain the proportion of young adults between 18 and 37 years of age who live with their parents when the household

is first interviewed, and leave in the following quarter. The proportion is computed by eligibility status, county of residence and period.

2. Standard errors obtained from OLS regressions, corrected by heteroscedasticity and correlation between observations at the individual level.

3. The D-in-D-in-D estimate in column 3,row 4 is obtained substracting the D-in-D estimate in row 7 , column 3 from the $D$-in-D estimate in row 3 , column 3 
Table 5: The impact of the 1999 reform on the probability of borrowing

\begin{tabular}{|c|c|c|c|c|}
\hline Estimation method: Probit. & $(1)$ & $(2)$ & $(3)$ & $(4)$ \\
\hline \multirow[t]{2}{*}{ 1. ELIG1*HIGHPRICE*POST99 } & -0.040 & -0.040 & -0.036 & -0.036 \\
\hline & $(0.009)^{* * *}$ & $(0.009)^{* * *}$ & $(0.009)^{* * *}$ & $(0.009)^{* * *}$ \\
\hline \multirow[t]{2}{*}{ 2. ELIG2*HIGHPRICE*POST99 } & -0.032 & -0.031 & -0.029 & -0.029 \\
\hline & $(0.004)^{\star \star *}$ & $(0.004)^{* * *}$ & $(0.004)^{* * *}$ & $(0.004)^{\star \star *}$ \\
\hline \multirow[t]{2}{*}{ 3. ELIG3*HIGHPRICE*POST99 } & -0.023 & -0.023 & -0.021 & -0.019 \\
\hline & $(0.016)$ & $(0.016)$ & $(0.016)$ & $(0.018)$ \\
\hline \multirow[t]{2}{*}{ ELIG1_POST99 } & 0.070 & 0.066 & 0.061 & 0.061 \\
\hline & $(0.036)^{*}$ & $(0.036)^{*}$ & $(0.034)^{*}$ & $(0.034)^{*}$ \\
\hline \multirow[t]{2}{*}{ ELIG2_POST99 } & 0.106 & 0.100 & 0.092 & 0.091 \\
\hline & $(0.091)$ & $(0.088)$ & $(0.084)$ & $(0.083)$ \\
\hline \multirow[t]{2}{*}{ ELIG3_POST99 } & 0.163 & 0.155 & 0.139 & 0.133 \\
\hline & $(0.129)$ & $(0.126)$ & $(0.115)$ & $(0.114)$ \\
\hline \multirow[t]{2}{*}{ HIGHPRICE*POST99 } & 0.022 & 0.021 & 0.019 & 0.019 \\
\hline & $(0.019)$ & $(0.019)$ & $(0.018)$ & $(0.018)$ \\
\hline \multirow[t]{2}{*}{ ELIG1*HIGHPRICE } & 0.023 & 0.024 & 0.021 & 0.023 \\
\hline & $(0.038)$ & $(0.038)$ & $(0.035)$ & $(0.036)$ \\
\hline \multirow[t]{2}{*}{ ELIG2*HIGHPRICE } & -0.010 & -0.010 & -0.012 & -0.013 \\
\hline & $(0.027)$ & $(0.027)$ & $(0.022)$ & $(0.022)$ \\
\hline \multirow[t]{2}{*}{ ELIG3*HIGHPRICE } & 0.080 & 0.078 & 0.070 & 0.068 \\
\hline & $(0.053)$ & $(0.052)$ & $(0.048)$ & $(0.047)$ \\
\hline \multirow[t]{2}{*}{ ELIG1 } & -0.058 & -0.022 & -0.022 & -0.022 \\
\hline & $(0.023)^{* *}$ & $(0.021)$ & $(0.020)$ & $(0.020)$ \\
\hline \multirow[t]{2}{*}{ ELIG2 } & -0.020 & -0.012 & -0.014 & -0.015 \\
\hline & $(0.011)^{*}$ & $(0.015)$ & $(0.013)$ & $(0.013)$ \\
\hline \multirow[t]{2}{*}{ ELIG3 } & -0.011 & -0.004 & -0.003 & -0.003 \\
\hline & $(0.021)$ & $(0.026)$ & $(0.025)$ & $(0.025)$ \\
\hline \multirow[t]{2}{*}{ POST99 } & 0.002 & 0.001 & -0.007 & -0.006 \\
\hline & $(0.015)$ & $(0.014)$ & $(0.014)$ & $(0.014)$ \\
\hline \multirow[t]{2}{*}{ HIGHPRICE } & -0.039 & -0.037 & -0.034 & -0.034 \\
\hline & $(0.021)^{*}$ & $(0.021)^{*}$ & $(0.020)^{*}$ & $(0.020)^{*}$ \\
\hline \multirow[t]{2}{*}{ (Age of young adult - 25)/10 } & 0.046 & 0.043 & 0.039 & 0.039 \\
\hline & $(0.008)^{* * *}$ & $(0.008)^{* * *}$ & $(0.008)^{* * *}$ & $(0.008)^{\star * *}$ \\
\hline \multirow[t]{2}{*}{ (Age of young adult - 25)/10, squared } & -0.029 & -0.026 & -0.021 & -0.021 \\
\hline & $(0.009)^{* * *}$ & $(0.009)^{* * *}$ & $(0.009)^{* *}$ & $(0.009)^{\star *}$ \\
\hline \multirow[t]{2}{*}{ Female } & -0.026 & -0.025 & -0.024 & -0.024 \\
\hline & $(0.004)^{* * *}$ & $(0.004)^{* * *}$ & $(0.004)^{* * *}$ & $(0.004)^{* * *}$ \\
\hline \multirow[t]{2}{*}{ Age of head in origin household - 57} & -0.013 & -0.013 & -0.012 & -0.011 \\
\hline & $(0.004)^{* * *}$ & $(0.004)^{* * *}$ & $(0.004)^{* * *}$ & $(0.004)^{* * *}$ \\
\hline \multirow[t]{2}{*}{ Head in origin household is a female } & -0.007 & -0.007 & -0.008 & -0.007 \\
\hline & $(0.005)$ & $(0.005)$ & $(0.005)$ & $(0.005)$ \\
\hline \multirow[t]{2}{*}{ Logarithm of labor income, young adult } & & 0.021 & 0.018 & 0.018 \\
\hline & & $(0.008)^{* * *}$ & $(0.009)^{*}$ & $(0.009)^{* *}$ \\
\hline Family size & & & -0.003 & -0.003 \\
\hline & & & $(0.002)$ & $(0.002)$ \\
\hline Young adult completed 6th grade or less & & & 0.003 & 0.002 \\
\hline & & & $(0.006)$ & $(0.006)$ \\
\hline Secondary schooling & & & 0.012 & 0.012 \\
\hline & & & $(0.007)^{*}$ & $(0.007)^{*}$ \\
\hline Logarithm of labor income of parent & & & & -0.003 \\
\hline & & & & $(0.004)$ \\
\hline
\end{tabular}


Table 5: The impact of the 1999 reform on the probability of borrowing (continued)

\begin{tabular}{|c|c|c|c|c|}
\hline 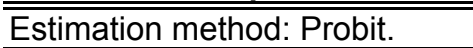 & (1) & $(2)$ & (3) & $(4)$ \\
\hline Parent reports no labor income & & & & $\begin{array}{l}-0.008 \\
(0.005)\end{array}$ \\
\hline District dummies? & no & no & no & yes \\
\hline Number of observations & 6467 & 6467 & 6467 & 6467 \\
\hline
\end{tabular}

1. Dependent variable takes value 1 if young adult signed a loan in the last two years

2. Sample: matched IE-CRC sample. The sample contains 5385 young adults. A young adult who

is observed only before the reform contributes one observation. If he or she is observed only after the reform, he or she contributes another observation. If he or she is observed both before and after, she contributes two observations.

3. Estimates shown are the impact of the independent variable on the probability of getting a loan, holding the rest of the covariates at their sample means.

4. ELIG, ELIG2, ELIG3 are binary variables that take value 1 if young adult is eligible for class 1 ,

2 and for the 3rd subsidy

5. HIGHPRICE takes value 1 if the average price per squared meter in the county of of residence was below the country-level median in 1998

6. ${ }^{*},{ }^{* *},{ }^{* * *}$ over the standard error indicates that the coefficient is significantly different from zero at the $10 \% ; 5 \%$; and $1 \%$ confidence levels, respectively. Standard errors are corrected for heteroscedas ticity and arbitrary correlation between observations from the same individual. 
Table 6: The impact of the 1999 and 2002 reforms on the probability of nest-leaving

\begin{tabular}{|c|c|c|c|}
\hline Estimation metod: Probit & $(1)$ & $(2)$ & (3) \\
\hline \multirow[t]{2}{*}{ 1. ELIG1*HIGH PRICE*POST99 } & -0.018 & -0.018 & -0.018 \\
\hline & $(0.006)^{\star * *}$ & $(0.006)^{\star * *}$ & $(0.006)^{\star * *}$ \\
\hline \multirow[t]{2}{*}{ 2. ELIG2*HIGH PRICE*POST99 } & -0.016 & -0.016 & -0.016 \\
\hline & $(0.006)^{\star * *}$ & $(0.006)^{* * *}$ & $(0.006)^{* * *}$ \\
\hline \multirow[t]{2}{*}{ 3. ELIG3*HIGH PRICE*POST99 } & -0.018 & -0.018 & -0.018 \\
\hline & $(0.007)^{\star \star \star}$ & $(0.007)^{\star \star *}$ & $(0.006)^{* * *}$ \\
\hline \multirow[t]{2}{*}{ 4. ELIG1*HIGH PRICE*POST02 } & 0.004 & 0.004 & 0.003 \\
\hline & $(0.013)$ & $(0.013)$ & $(0.013)$ \\
\hline \multirow[t]{2}{*}{ 5. ELIG2*HIGH PRICE*POST02 } & 0.008 & 0.008 & 0.008 \\
\hline & $(0.023)$ & $(0.023)$ & $(0.023)$ \\
\hline \multirow[t]{2}{*}{ 6. ELIG3*HIGH PRICE*POST02 } & -0.002 & -0.002 & -0.002 \\
\hline & $(0.022)$ & $(0.023)$ & $(0.022)$ \\
\hline \multirow[t]{2}{*}{ ELIG1*POST99 } & 0.016 & 0.016 & 0.017 \\
\hline & $(0.014)$ & $(0.013)$ & $(0.014)$ \\
\hline \multirow[t]{2}{*}{ ELIG2*POST99 } & 0.025 & 0.025 & 0.025 \\
\hline & $(0.026)$ & $(0.026)$ & $(0.026)$ \\
\hline \multirow[t]{2}{*}{ ELIG3*POST99 } & 0.047 & 0.047 & 0.048 \\
\hline & $(0.052)$ & $(0.053)$ & $(0.053)$ \\
\hline \multirow[t]{2}{*}{ ELIG1*POST02 } & -0.007 & -0.007 & -0.007 \\
\hline & $(0.008)$ & $(0.008)$ & $(0.008)$ \\
\hline \multirow[t]{2}{*}{ ELIG2*POST02 } & -0.006 & -0.006 & -0.006 \\
\hline & $(0.010)$ & $(0.010)$ & $(0.010)$ \\
\hline \multirow[t]{2}{*}{ ELIG3*POST02 } & -0.003 & -0.003 & -0.003 \\
\hline & $(0.017)$ & $(0.017)$ & $(0.017)$ \\
\hline \multirow[t]{2}{*}{ ELIG1*HIGH PRICE } & 0.005 & 0.005 & 0.005 \\
\hline & $(0.009)$ & $(0.009)$ & $(0.009)$ \\
\hline \multirow[t]{2}{*}{ ELIG2*HIGH PRICE } & 0.005 & 0.005 & 0.005 \\
\hline & $(0.014)$ & $(0.015)$ & $(0.015)$ \\
\hline \multirow[t]{2}{*}{ ELIG3*HIGH PRICE } & 0.036 & 0.037 & 0.037 \\
\hline & $(0.039)$ & $(0.040)$ & $(0.040)$ \\
\hline \multirow[t]{2}{*}{ HIGH PRICE*POST99 } & 0.024 & 0.024 & 0.025 \\
\hline & $(0.020)$ & $(0.020)$ & $(0.020)$ \\
\hline \multirow[t]{2}{*}{ HIGH PRICE*POST02 } & -0.008 & -0.008 & -0.007 \\
\hline & $(0.009)$ & $(0.009)$ & $(0.009)$ \\
\hline \multirow[t]{2}{*}{ ELIG1 } & -0.006 & -0.003 & -0.005 \\
\hline & $(0.007)$ & $(0.008)$ & $(0.008)$ \\
\hline \multirow[t]{2}{*}{ ELIG2 } & -0.003 & -0.002 & -0.002 \\
\hline & $(0.009)$ & $(0.009)$ & $(0.009)$ \\
\hline \multirow[t]{2}{*}{ ELIG3 } & -0.014 & -0.013 & -0.013 \\
\hline & $(0.008)^{*}$ & $(0.008)^{*}$ & $(0.008)^{*}$ \\
\hline \multirow[t]{2}{*}{ Post 1999 dummy (zero after 2002) } & -0.012 & -0.013 & -0.013 \\
\hline & $(0.009)$ & $(0.009)$ & $(0.009)$ \\
\hline Post 2002 dummy & 0.014 & 0.013 & 0.013 \\
\hline & $(0.011)$ & $(0.011)$ & $(0.011)$ \\
\hline HIGH PRICE & -0.003 & -0.004 & -0.003 \\
\hline & $(0.008)$ & $(0.008)$ & $(0.008)$ \\
\hline (Age of the young - 25)/10 & 0.008 & 0.010 & 0.010 \\
\hline & $(0.002)^{* * *}$ & $(0.003)^{* * *}$ & $(0.003)^{* * *}$ \\
\hline (Age of the yound - 25$) / 10$, squared & -0.017 & -0.017 & -0.018 \\
\hline & $(0.003)^{\star * *}$ & $(0.003)^{\star * *}$ & $(0.003)^{* * *}$ \\
\hline Young adult is a female & 0.005 & 0.005 & 0.006 \\
\hline & $(0.002)^{\star * *}$ & $(0.002)^{\star * *}$ & $(0.002)^{\star * *}$ \\
\hline
\end{tabular}


Table 6: The impact of the 1999 and 2002 reforms on the probability of nest-leaving

Estimation metod: Probit

(Age of the parent - 57)/10

$-0.0015$

$-0.0015$

Income of the young

$(0.0013)$

$(0.0013)$

0.002

0.003

Logarithm of parental income

$(0.003)$

$(0.003)$

$-0.001$

Parent reports no income

Young adult has 6 th grade or less

$(0.002)$

$-0.001$

Young adult has at least high school

$(0.002)$

\begin{tabular}{lccc}
\hline Number of observations & 35,624 & 35,624 & 35,624 \\
Pseudo-R squared & .011 & .011 & .0122 \\
\hline
\end{tabular}

1. Sample of 9,314 young adults who live with their parents, drawn from the 1998-2004 waves of IE (see Table 2). The sample unit is a young adult in a quarter.

2. The dependent variable takes value 1 if the young adult is a dependent in a sample household in a quarter but not in the next. Households observed only in one quarter are excluded

3. Estimates shown are the impact of each variable on change in the probability of leaving the house of the parentshouse of the parents in a quarter, holding the rest of variables at sample means.

4. ELIG, ELIG2, ELIG3 are binary variables that take value 1 if young adult is eligible for class 1, 2, and 3 rd subsidies (the last group being a single group), respectively.

5. HIGHPRICE is a binary indicator that takes value 1 if the unit of price of housing in the county of residence was below the country-level median in 1998

6. Standard errors, in parentheses, are corrected for heteroscedasticity arbitrary correlation among observations belonging to the same individual.

7. ${ }^{*},{ }^{* *},{ }^{* * *}$ over the standard error indicates that the coefficient is significantly different from zero at the $10 \% ; 5 \%$; and $1 \%$ confidence levels, respectively. 
Table 7: The impact of the probability of getting a loan on establishing a new household

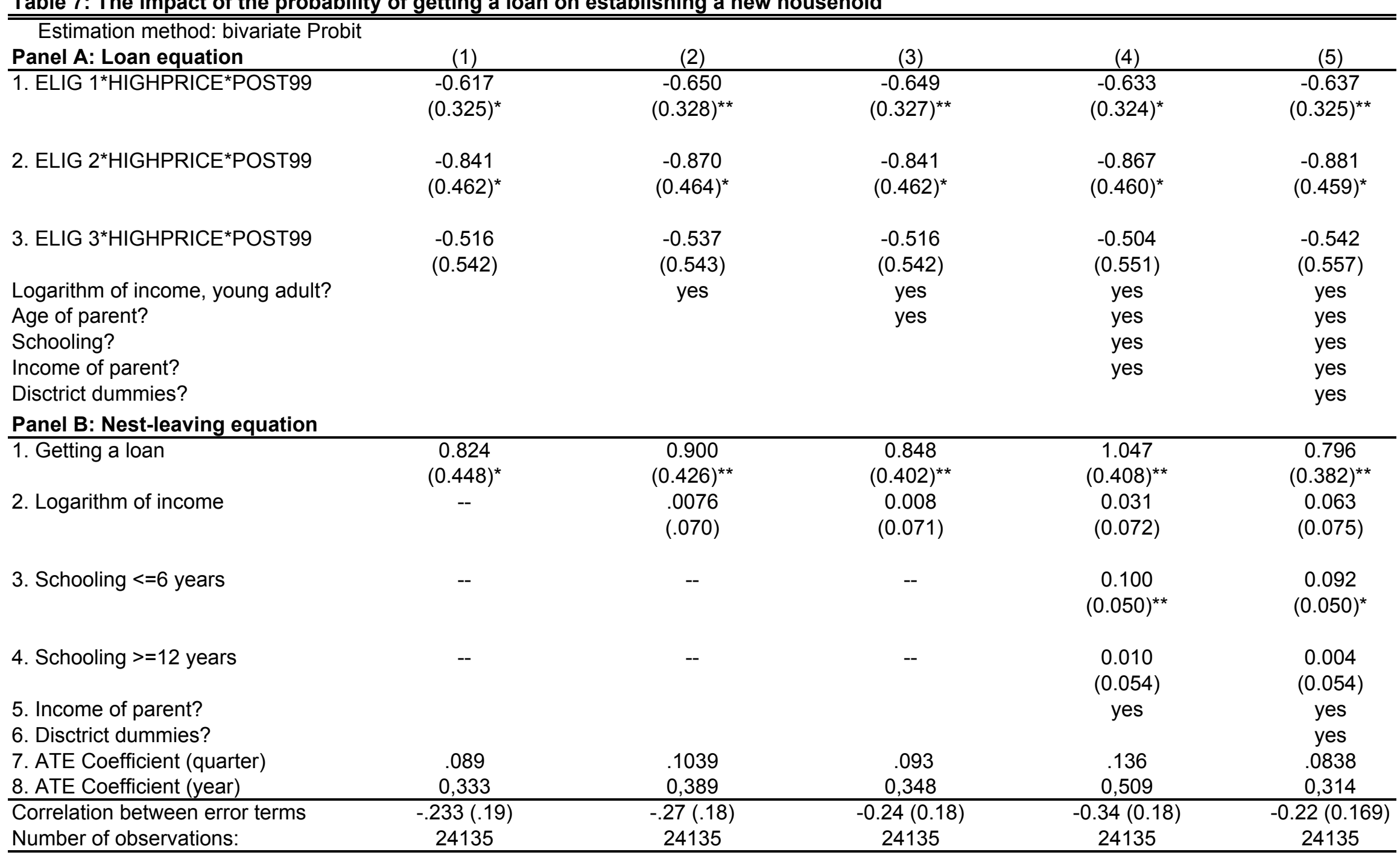

Sample: matched IE-CRC records. The unit of analysis is the young-adult quarter. Standard errors (in parentheses) are corrected for heteroscedasticity and arbitrary correlation between observations of the same individual. All coefficients but those in rows 7 and 8 of panel B are structural coefficients in the bivariate probit. ${ }^{* * *}$ denotes that the coefficient is significantly different from zero at the 10 and 5 percent confidence level. Appendix table A. 1 provide full detail. 
Table 8: The impact of the probability of getting a loan on establishin a new household (alternative specifications)

\begin{tabular}{|c|c|c|c|c|c|c|}
\hline $\begin{array}{l}\text { Sample: } \\
\text { Estimation method: } \\
\text { Panel A: First stage equation }\end{array}$ & $\begin{array}{c}\text { Eligibles class I, II } \\
\text { Bivariate probit } \\
\text { (1) }\end{array}$ & $\begin{array}{c}\text { Age above } 22 \\
\text { Bivariate probit } \\
\text { (2) } \\
\end{array}$ & $\begin{array}{c}\text { Males } \\
\text { Bivariate probit } \\
(3) \\
\end{array}$ & $\begin{array}{c}\text { Females } \\
\text { Bivariate Probit } \\
(4) \\
\end{array}$ & $\begin{array}{c}\text { All } \\
\text { TSLS } \\
(5) \\
\end{array}$ & $\begin{array}{c}\text { All, loan amount } \\
\text { TSLS } \\
(6) \\
\end{array}$ \\
\hline ELIG1*POST99*HIGHPRICE & no & $\begin{array}{c}-.703 \\
(.3467)^{\star *}\end{array}$ & $\begin{array}{l}-.819 \\
(.447)^{*}\end{array}$ & $\begin{array}{l}-.305 \\
(.55)\end{array}$ & $\begin{array}{l}-.0849 \\
(.044)^{\star}\end{array}$ & $\begin{array}{l}-3.758 \\
(1.936)^{*}\end{array}$ \\
\hline ELIG2*POST99*HIGHPRICE & no & \multicolumn{2}{|c|}{$\begin{array}{l}\text { constrained to be the same } \\
\text { as eligible } 1\end{array}$} & & \multicolumn{2}{|c|}{$\begin{array}{l}\text { constrained to be the same } \\
\text { as eligible } 1\end{array}$} \\
\hline ELIG3*POST99*HIGHPRICE & no & \multicolumn{2}{|c|}{$\begin{array}{c}\text { constrained to be the same } \\
\text { as eligible } 1\end{array}$} & & \multicolumn{2}{|c|}{ constrained to be the same } \\
\hline POST99*HIGHPRICE & $\begin{array}{l}-.22 \\
(.12)^{*}\end{array}$ & $\begin{array}{l}.501 \\
(.32)\end{array}$ & & & & \\
\hline Logarithm of income, young adult? & yes & yes & yes & yes & yes & yes \\
\hline District dummies? & no & no & no & no & no & no \\
\hline Schooling? & no & no & no & no & no & no \\
\hline $\begin{array}{l}\text { Age and income of parent? } \\
\text { F-statistic of first-stage regression }\end{array}$ & no & no & no & no & $\begin{array}{c}\text { no } \\
12.75\end{array}$ & $\begin{array}{c}\text { no } \\
8.37\end{array}$ \\
\hline \multicolumn{7}{|l|}{ Panel B: Second stage equation } \\
\hline 1. Getting a loan & $\begin{array}{l}1.016 \\
(.60)^{*}\end{array}$ & $\begin{array}{c}.971 \\
(.57)^{*}\end{array}$ & $\begin{array}{l}1.185 \\
(.572)^{\star *}\end{array}$ & $\begin{array}{l}-.489 \\
(.820)\end{array}$ & $\begin{array}{c}.144 \\
(.080)^{*}\end{array}$ & $\begin{array}{l}.00366 \\
(.0019)^{\star}\end{array}$ \\
\hline 2. ATE Coefficient (quarter) & .127 & .123 & .156 & -.019 & .144 & .00366 \\
\hline 3. ATE Coefficient (year) & 0,475 & 0,460 & 0,587 & $-0,071$ & 0,539 & 0,014 \\
\hline Number of observations: & 20,929 & 16,349 & 13,635 & 10,500 & 24,135 & 24,135 \\
\hline
\end{tabular}

1. The nest-leaving equation in all specifications includes the deviation of the age of the young adult from 25 and its square.

In specifications other than (3) and (4), the nest-leaving equation also includes a dummy for female.

2. In specifications (2)-(6), the nest-leaving equation includes indicators of eligibility (a single indicator for eligibles for the 1st, 2nd and 3rd subsidy), whether lived in an area that had price in 1998 below the mean, and post-1999 reform, as well as second order interactions between the indicators of eligibility, location and time. Specification (1) only includes indicators of location and of post-99 reform.

3. Standard errors in parentheses are corrected for heteroscedasticity and correlation between observations of the same individual.

4. ${ }^{*},{ }^{* *}$ denotes that the coefficient is significantly different from zero at the 10 and 5 percent confidence level. 
Panel A: linear regression of nest leaving on country dummies.

Dependent variable takes value 1 if the young left the house of the parents, 0 otherwise

\begin{tabular}{|c|c|c|c|}
\hline Estimation method: & $\begin{array}{l}\text { OLS } \\
(1)\end{array}$ & $\begin{array}{l}\text { Restricted } \\
\text { OLS, } \delta_{1}=.34 \\
(2)\end{array}$ & $\begin{array}{l}\text { Restricted } \\
\text { OLS, } \delta_{1}=.54 \\
(3)\end{array}$ \\
\hline \multirow[t]{2}{*}{$($ Age -25$) / 10$} & .077 & .0656 & .058 \\
\hline & $(.0033)$ & $(.003)$ & $(.0029)$ \\
\hline \multirow[t]{2}{*}{$($ Age -25$) / 10$, squared } & -.082 & -.071 & -.064 \\
\hline & $(.0034)$ & $(.00314)$ & $(.003)$ \\
\hline \multirow[t]{2}{*}{ Parental household size } & .0045 & .0043 & .004 \\
\hline & $(.00075)$ & $(.0007)$ & $(.0007)$ \\
\hline \multicolumn{4}{|l|}{ Country intercepts: } \\
\hline \multirow[t]{2}{*}{ Germany } & -0.002 & 0.000 & 0.001 \\
\hline & $(0.008)$ & $(0.007)$ & $(0.007)$ \\
\hline \multirow[t]{2}{*}{ Denmark } & 0.151 & 0.139 & 0.136 \\
\hline & $(0.018)$ & $(0.017)$ & $(0.017)$ \\
\hline \multirow[t]{2}{*}{ Netherlands } & 0.030 & 0.024 & 0.023 \\
\hline & $(0.010)$ & $(0.010)$ & $(0.010)$ \\
\hline \multirow[t]{2}{*}{ United Kingdom } & 0.053 & 0.034 & 0.032 \\
\hline & $(0.010)$ & $(0.009)$ & $(0.009)$ \\
\hline \multirow[t]{2}{*}{ France } & 0.021 & 0.023 & 0.023 \\
\hline & $(0.008)$ & $(0.007)$ & $(0.007)$ \\
\hline \multirow[t]{2}{*}{ Ireland } & -0.051 & -0.053 & -0.053 \\
\hline & $(0.007)$ & $(0.007)$ & $(0.006)$ \\
\hline \multirow[t]{2}{*}{ Italy } & -0.062 & -0.057 & -0.057 \\
\hline & $(0.006)$ & $(0.006)$ & $(0.006)$ \\
\hline \multirow[t]{2}{*}{ Spain } & -0.058 & -0.060 & -0.060 \\
\hline & $(0.007)$ & $(0.006)$ & $(0.006)$ \\
\hline \multirow[t]{2}{*}{ Portugal } & -0.052 & -0.052 & -0.052 \\
\hline & $(0.007)$ & $(0.006)$ & $(0.006)$ \\
\hline Wave dummies? & yes & yes & yes \\
\hline \multirow[t]{2}{*}{ Constant: } & .131 & .119 & .126 \\
\hline & $(.0068)$ & $(.0063)$ & $(.007)$ \\
\hline Sample size: & 68,728 & 68,728 & 68,728 \\
\hline
\end{tabular}

Panel B: dispersion in country dummies.

Model:

Variance of country dummies

(standard error of the variance)
(1)

.0039

$(.00052)$
(2)

.00339

$(.000457)$
(3)

.00312

$(.000426)$

Source: European Community Household Panel

1. Sample described in footnotes to Table 1, excluding nest leavers not tracked by the ECHP into their new household.

2. Standard errors corrected by heteroscedasticity and arbitrary autocorrelation across observations of the same individual. 
Table A.1: The impact of the probability of getting a loan on cohabitation, bivariate probit

\begin{tabular}{|c|c|c|c|c|}
\hline & \multicolumn{2}{|c|}{ Model I } & \multicolumn{2}{|c|}{ Model 2} \\
\hline & $\begin{array}{c}\text { Eq. 1: } \\
\text { New loan }\end{array}$ & $\begin{array}{l}\text { Eq. 2: Nest } \\
\text { leaving }\end{array}$ & $\begin{array}{c}\text { Eq. 1: } \\
\text { New loan }\end{array}$ & $\begin{array}{l}\text { Eq. 2: Nest } \\
\text { leaving }\end{array}$ \\
\hline \multirow[t]{2}{*}{ Signing a loan } & -- & 0.824 & -- & 0.900 \\
\hline & -- & $(0.448)^{*}$ & -- & $(0.426)^{\star *}$ \\
\hline \multirow[t]{2}{*}{ ELIG 1*HIGHPRICE*POST99 } & -0.617 & -- & -0.650 & -- \\
\hline & $(0.325)^{*}$ & -- & $(0.328)^{\star *}$ & -- \\
\hline \multirow[t]{2}{*}{ ELIG 2*HIGHPRICE*POST99 } & -0.841 & -- & -0.870 & -- \\
\hline & $(0.462)^{*}$ & -- & $(0.464)^{*}$ & -- \\
\hline \multirow{2}{*}{ ELIG 3*HIGHPRICE*POST99 } & -0.516 & -- & -0.537 & -- \\
\hline & $(0.542)$ & -- & $(0.543)$ & -- \\
\hline \multirow[t]{2}{*}{ ELIG 1* POST99 } & 0.385 & -0.018 & 0.384 & -0.018 \\
\hline & $(0.269)$ & $(0.119)$ & $(0.273)$ & $(0.118)$ \\
\hline \multirow[t]{2}{*}{ ELIG 2* POST99 } & 0.618 & 0.022 & 0.625 & 0.021 \\
\hline & $(0.371)^{*}$ & $(0.170)$ & $(0.373)^{*}$ & $(0.170)$ \\
\hline \multirow[t]{2}{*}{ ELIG 3* POST99 } & 0.736 & 0.027 & 0.739 & 0.024 \\
\hline & $(0.440)^{*}$ & $(0.219)$ & $(0.442)^{*}$ & $(0.219)$ \\
\hline \multirow[t]{2}{*}{ ELIG 1* highprice } & 0.192 & -0.110 & 0.196 & -0.106 \\
\hline & $(0.209)$ & $(0.125)$ & $(0.210)$ & $(0.125)$ \\
\hline \multirow[t]{2}{*}{ ELIG 2 * highprice } & 0.170 & -0.131 & 0.192 & -0.126 \\
\hline & (0.323) & $(0.176)$ & (0.323) & $(0.176)$ \\
\hline \multirow[t]{2}{*}{ ELIG 3 * higprice } & 0.037 & 0.162 & 0.054 & 0.166 \\
\hline & $(0.434)$ & $(0.235)$ & $(0.433)$ & $(0.235)$ \\
\hline \multirow[t]{2}{*}{ Highprice * POST99 } & 0.428 & -0.080 & 0.455 & -0.080 \\
\hline & $(0.301)$ & $(0.074)$ & $(0.305)$ & $(0.074)$ \\
\hline \multirow[t]{2}{*}{ ELIG 1} & -0.470 & 0.051 & -0.086 & 0.059 \\
\hline & $(0.163)^{\star * *}$ & $(0.119)$ & $(0.196)$ & $(0.140)$ \\
\hline \multirow[t]{2}{*}{ ELIG 2} & -0.347 & 0.111 & -0.158 & 0.114 \\
\hline & $(0.266)$ & $(0.168)$ & $(0.271)$ & $(0.171)$ \\
\hline \multirow[t]{2}{*}{ ELIG 3} & -0.219 & -0.140 & -0.083 & -0.138 \\
\hline & (0.354) & $(0.222)$ & (0.355) & $(0.224)$ \\
\hline \multirow[t]{2}{*}{ Highprice } & 0.108 & 0.098 & 0.088 & 0.093 \\
\hline & $(0.190)$ & $(0.124)$ & (0.191) & $(0.124)$ \\
\hline \multirow[t]{2}{*}{ POST99 } & -0.212 & 0.025 & -0.244 & 0.024 \\
\hline & $(0.255)$ & $(0.121)$ & $(0.260)$ & $(0.120)$ \\
\hline \multirow{2}{*}{ Age of young adult -25} & 0.451 & 0.090 & 0.410 & 0.088 \\
\hline & $(0.075)^{\star * *}$ & $(0.050)^{*}$ & $(0.076)^{\star * *}$ & $(0.050)^{*}$ \\
\hline \multirow[t]{2}{*}{ Age of young adult, squared } & -0.501 & -0.320 & -0.447 & -0.317 \\
\hline & $(0.120)^{* * *}$ & $(0.083)^{* * *}$ & $(0.120)^{* * *}$ & $(0.083)^{* * *}$ \\
\hline \multirow[t]{2}{*}{ Young adult is a female } & -0.382 & 0.140 & -0.360 & 0.142 \\
\hline & $(0.058)^{* * *}$ & $(0.038)^{* * *}$ & $(0.058)^{* * *}$ & $(0.037)^{* * *}$ \\
\hline Log income of young adult & -- & -- & 0.372 & .0076 \\
\hline & -- & -- & $(0.099)^{\star * *}$ & $(.070)$ \\
\hline Age of head in parental house -57 & -- & -- & -- & -- \\
\hline & -- & -- & -- & -- \\
\hline Head of parental household female & -- & -- & -- & -- \\
\hline & -- & -- & -- & -- \\
\hline District dummies? & no & no & no & no \\
\hline Constant & -1.261 & -2.090 & -1.597 & -2.099 \\
\hline & $(0.152)^{\star * \star}$ & $(0.120)^{\star * *}$ & $(0.179)^{\star * *}$ & $(0.136)^{\star \star \star *}$ \\
\hline Correlation between unobservables & $-.233(.19)$ & & $-.27(.18)$ & \\
\hline Observations & 24135 & & 24135 & \\
\hline
\end{tabular}




\begin{tabular}{|c|c|c|c|c|c|c|}
\hline & \multicolumn{2}{|l|}{ Model 3} & \multicolumn{2}{|c|}{ Model 4} & \multicolumn{2}{|l|}{ Model 5} \\
\hline & $\begin{array}{l}\text { Eq. 1: } \\
\text { New loan }\end{array}$ & $\begin{array}{l}\text { Eq. 2: Nest } \\
\text { leaving }\end{array}$ & $\begin{array}{c}\text { Eq. 1: } \\
\text { New loan }\end{array}$ & $\begin{array}{l}\text { Eq. 2: Nest } \\
\text { leaving }\end{array}$ & $\begin{array}{c}\text { Eq. 1: } \\
\text { New loan }\end{array}$ & $\begin{array}{l}\text { Eq. 2: Nest } \\
\text { leaving }\end{array}$ \\
\hline Signing a loan & $\begin{array}{l}- \\
--\end{array}$ & $\begin{array}{c}0.848 \\
(0.402)^{* *}\end{array}$ & & $\begin{array}{c}1.047 \\
(0.408)^{* *}\end{array}$ & & $\begin{array}{c}0.796 \\
(0.382)^{\star *}\end{array}$ \\
\hline ELIG 1*HIGHPRICE*POST99 & $\begin{array}{c}-0.649 \\
(0.327)^{\star *}\end{array}$ & $\begin{array}{l}-- \\
--\end{array}$ & $\begin{array}{c}-0.633 \\
(0.324)^{*}\end{array}$ & -- & $\begin{array}{c}-0.637 \\
(0.325)^{\star *}\end{array}$ & $\begin{array}{l}-- \\
--\end{array}$ \\
\hline ELIG 2*HIGHPRICE*POST99 & $\begin{array}{c}-0.861 \\
(0.463)^{*}\end{array}$ & $\begin{array}{l}-- \\
--\end{array}$ & $\begin{array}{c}-0.867 \\
(0.460)^{*}\end{array}$ & $\begin{array}{l}-- \\
--\end{array}$ & $\begin{array}{c}-0.881 \\
(0.459)^{*}\end{array}$ & $\begin{array}{l}-- \\
--\end{array}$ \\
\hline ELIG 3*HIGHPRICE*POST99 & $\begin{array}{l}-0.526 \\
(0.554)\end{array}$ & $\begin{array}{l}-- \\
--\end{array}$ & $\begin{array}{l}-0.504 \\
(0.551)\end{array}$ & $\begin{array}{l}-- \\
--\end{array}$ & $\begin{array}{l}-0.542 \\
(0.557)\end{array}$ & -- \\
\hline ELIG 1* POST99 & $\begin{array}{c}0.366 \\
(0.273)\end{array}$ & $\begin{array}{l}-0.017 \\
(0.119)\end{array}$ & $\begin{array}{c}0.364 \\
(0.269)\end{array}$ & $\begin{array}{l}-0.011 \\
(0.119)\end{array}$ & $\begin{array}{c}0.390 \\
(0.270)\end{array}$ & $\begin{array}{l}-0.012 \\
(0.119)\end{array}$ \\
\hline ELIG 2* POST99 & $\begin{array}{c}0.583 \\
(0.373)\end{array}$ & $\begin{array}{c}0.023 \\
(0.170)\end{array}$ & $\begin{array}{c}0.598 \\
(0.369)\end{array}$ & $\begin{array}{c}0.022 \\
(0.170)\end{array}$ & $\begin{array}{c}0.620 \\
(0.367)^{*}\end{array}$ & $\begin{array}{c}0.015 \\
(0.171)\end{array}$ \\
\hline ELIG 3* POST99 & $\begin{array}{c}0.698 \\
(0.452)\end{array}$ & $\begin{array}{c}0.031 \\
(0.218)\end{array}$ & $\begin{array}{c}0.695 \\
(0.452)\end{array}$ & $\begin{array}{c}0.023 \\
(0.219)\end{array}$ & $\begin{array}{c}0.720 \\
(0.460)\end{array}$ & $\begin{array}{c}0.040 \\
(0.219)\end{array}$ \\
\hline ELIG 1* highprice & $\begin{array}{c}0.182 \\
(0.211)\end{array}$ & $\begin{array}{l}-0.107 \\
(0.125)\end{array}$ & $\begin{array}{c}0.199 \\
(0.210)\end{array}$ & $\begin{array}{l}-0.102 \\
(0.125)\end{array}$ & $\begin{array}{c}0.219 \\
(0.210)\end{array}$ & $\begin{array}{l}-0.110 \\
(0.125)\end{array}$ \\
\hline ELIG 2 * highprice & $\begin{array}{c}0.182 \\
(0.324)\end{array}$ & $\begin{array}{l}-0.124 \\
(0.176)\end{array}$ & $\begin{array}{c}0.215 \\
(0.324)\end{array}$ & $\begin{array}{l}-0.115 \\
(0.177)\end{array}$ & $\begin{array}{c}0.253 \\
(0.322)\end{array}$ & $\begin{array}{l}-0.114 \\
(0.177)\end{array}$ \\
\hline ELIG $3 *$ higprice & $\begin{array}{c}0.036 \\
(0.444)\end{array}$ & $\begin{array}{c}0.164 \\
(0.235)\end{array}$ & $\begin{array}{c}0.029 \\
(0.440)\end{array}$ & $\begin{array}{c}0.163 \\
(0.235)\end{array}$ & $\begin{array}{c}0.050 \\
(0.450)\end{array}$ & $\begin{array}{c}0.170 \\
(0.234)\end{array}$ \\
\hline Highprice * POST99 & $\begin{array}{c}0.458 \\
(0.303)\end{array}$ & $\begin{array}{l}-0.084 \\
(0.074)\end{array}$ & $\begin{array}{c}0.438 \\
(0.300)\end{array}$ & $\begin{array}{l}-0.078 \\
(0.074)\end{array}$ & $\begin{array}{c}0.442 \\
(0.300)\end{array}$ & $\begin{array}{l}-0.079 \\
(0.074)\end{array}$ \\
\hline ELIG 1 & $\begin{array}{c}-0.086 \\
(0.198)\end{array}$ & $\begin{array}{c}0.054 \\
(0.141)\end{array}$ & $\begin{array}{l}-0.061 \\
(0.197)\end{array}$ & $\begin{array}{c}0.036 \\
(0.141)\end{array}$ & $\begin{array}{l}-0.113 \\
(0.197)\end{array}$ & $\begin{array}{l}-0.005 \\
(0.122)\end{array}$ \\
\hline ELIG 2 & $\begin{array}{l}-0.138 \\
(0.273)\end{array}$ & $\begin{array}{c}0.108 \\
(0.171)\end{array}$ & $\begin{array}{l}-0.149 \\
(0.272)\end{array}$ & $\begin{array}{c}0.106 \\
(0.172)\end{array}$ & $\begin{array}{l}-0.224 \\
(0.270)\end{array}$ & $\begin{array}{c}0.081 \\
(0.170)\end{array}$ \\
\hline ELIG 3 & $\begin{array}{l}-0.057 \\
(0.364)\end{array}$ & $\begin{array}{l}-0.140 \\
(0.223)\end{array}$ & $\begin{array}{c}-0.065 \\
(0.361)\end{array}$ & $\begin{array}{l}-0.139 \\
(0.223)\end{array}$ & $\begin{array}{l}-0.095 \\
(0.373)\end{array}$ & $\begin{array}{l}-0.168 \\
(0.222)\end{array}$ \\
\hline Highprice & $\begin{array}{c}0.083 \\
(0.192)\end{array}$ & $\begin{array}{c}0.092 \\
(0.124)\end{array}$ & $\begin{array}{c}0.058 \\
(0.192)\end{array}$ & $\begin{array}{c}0.101 \\
(0.124)\end{array}$ & $\begin{array}{l}-0.063 \\
(0.198)\end{array}$ & $\begin{array}{c}0.112 \\
(0.129)\end{array}$ \\
\hline POST99 & $\begin{array}{l}-0.234 \\
(0.259)\end{array}$ & $\begin{array}{c}0.024 \\
(0.121)\end{array}$ & $\begin{array}{l}-0.222 \\
(0.255)\end{array}$ & $\begin{array}{c}0.018 \\
(0.121)\end{array}$ & $\begin{array}{l}-0.238 \\
(0.256)\end{array}$ & $\begin{array}{c}0.026 \\
(0.121)\end{array}$ \\
\hline Age of young adult -25 & $\begin{array}{c}0.622 \\
(0.101)^{\star * * *}\end{array}$ & $\begin{array}{c}0.089 \\
(0.062)\end{array}$ & $\begin{array}{c}0.589 \\
(0.101)^{\star * *}\end{array}$ & $\begin{array}{c}0.082 \\
(0.062)\end{array}$ & $\begin{array}{c}0.575 \\
(0.103)^{\star * *}\end{array}$ & $\begin{array}{c}0.103 \\
(0.062)^{*}\end{array}$ \\
\hline Age of young adult, squared & $\begin{array}{c}-0.459 \\
(0.120)^{\star * *}\end{array}$ & $\begin{array}{c}-0.321 \\
(0.083)^{\star * *}\end{array}$ & $\begin{array}{c}-0.405 \\
(0.122)^{\star \star \star}\end{array}$ & $\begin{array}{c}-0.327 \\
(0.084)^{\star * *}\end{array}$ & $\begin{array}{c}-0.396 \\
(0.121)^{\star \star \star}\end{array}$ & $\begin{array}{c}-0.343 \\
(0.084)^{\star \star * *}\end{array}$ \\
\hline Young adult is a female & $\begin{array}{c}-0.353 \\
(0.058)^{\star * *}\end{array}$ & $\begin{array}{c}0.141 \\
(0.038)^{\star * *}\end{array}$ & $\begin{array}{c}-0.385 \\
(0.059)^{\star \star *}\end{array}$ & $\begin{array}{c}0.159 \\
(0.038)^{\star * \star}\end{array}$ & $\begin{array}{c}-0.375 \\
(0.059)^{\star \star \star *}\end{array}$ & $\begin{array}{c}0.152 \\
(0.039)^{\star * *}\end{array}$ \\
\hline Log income of young adult & $\begin{array}{c}0.353 \\
(0.100)^{\star * *}\end{array}$ & $\begin{array}{c}0.008 \\
(0.071)\end{array}$ & $\begin{array}{c}0.325 \\
(0.099)^{\star * *}\end{array}$ & $\begin{array}{c}0.031 \\
(0.072)\end{array}$ & $\begin{array}{c}0.307 \\
(0.100)^{\star \star \star}\end{array}$ & $\begin{array}{c}0.063 \\
(0.075)\end{array}$ \\
\hline Age of parent- 57 & $\begin{array}{c}-0.174 \\
(0.051)^{\star \star *}\end{array}$ & $\begin{array}{l}-0.006 \\
(0.029)\end{array}$ & $\begin{array}{c}-0.135 \\
(0.052)^{\star * \star}\end{array}$ & $\begin{array}{l}-0.019 \\
(0.030)\end{array}$ & $\begin{array}{c}-0.135 \\
(0.052)^{\star \star \star}\end{array}$ & $\begin{array}{l}-0.022 \\
(0.030)\end{array}$ \\
\hline Head of household female & $\begin{array}{c}-0.093 \\
(0.071)\end{array}$ & $\begin{array}{c}0.056 \\
(0.046)\end{array}$ & -- & $\begin{array}{l}-- \\
--\end{array}$ & $\begin{array}{l}-- \\
--\end{array}$ & $\begin{array}{l}-- \\
--\end{array}$ \\
\hline Completed 6th grade or less & -- & $\begin{array}{l}-- \\
--\end{array}$ & $\begin{array}{c}0.041 \\
(0.076)\end{array}$ & $\begin{array}{c}0.100 \\
(0.050)^{\star *}\end{array}$ & $\begin{array}{c}0.062 \\
(0.078)\end{array}$ & $\begin{array}{c}0.092 \\
(0.050)^{*}\end{array}$ \\
\hline Completed high school & $\begin{array}{l}-- \\
--\end{array}$ & $\begin{array}{l}-- \\
--\end{array}$ & $\begin{array}{c}0.205 \\
(0.077)^{\star * *}\end{array}$ & $\begin{array}{c}0.010 \\
(0.054)\end{array}$ & $\begin{array}{c}0.202 \\
(0.077)^{\star \star \star}\end{array}$ & $\begin{array}{c}0.004 \\
(0.054)\end{array}$ \\
\hline Logarithm of parental income & $\begin{array}{l}-- \\
--\end{array}$ & $\begin{array}{l}-- \\
--\end{array}$ & $\begin{array}{l}-0.049 \\
(0.050)\end{array}$ & $\begin{array}{l}-0.033 \\
(0.038)\end{array}$ & $\begin{array}{l}-0.055 \\
(0.050)\end{array}$ & $\begin{array}{l}-0.028 \\
(0.038)\end{array}$ \\
\hline $\begin{array}{l}\text { Parent does not report } \\
\text { labor income. }\end{array}$ & $\begin{array}{l}-- \\
--\end{array}$ & $\begin{array}{l}-- \\
--\end{array}$ & $\begin{array}{c}-0.172 \\
(0.060)^{\star * \star}\end{array}$ & $\begin{array}{c}0.042 \\
(0.041)\end{array}$ & $\begin{array}{c}-0.164 \\
(0.061)^{\star \star *}\end{array}$ & $\begin{array}{c}0.039 \\
(0.041)\end{array}$ \\
\hline
\end{tabular}


Table A1 (continued): The impact of the probability of getting a loan, bivariate probit

\begin{tabular}{|c|c|c|c|c|c|c|}
\hline & \multicolumn{2}{|l|}{ Model 3} & \multicolumn{2}{|c|}{ Model 4} & \multicolumn{2}{|l|}{ Model 5} \\
\hline & $\begin{array}{c}\text { Eq. 1: } \\
\text { New loan }\end{array}$ & $\begin{array}{l}\text { Eq. 2: Nest } \\
\text { leaving }\end{array}$ & $\begin{array}{c}\text { Eq. 1: } \\
\text { New loan }\end{array}$ & $\begin{array}{l}\text { Eq. 2: Nest } \\
\text { leaving }\end{array}$ & $\begin{array}{c}\text { Eq. 1: } \\
\text { New loan }\end{array}$ & $\begin{array}{l}\text { Eq. 2: Nest } \\
\text { leaving }\end{array}$ \\
\hline District dummies? & no & no & no & no & yes & yes \\
\hline Constant & $\begin{array}{c}-1.380 \\
(0.242)^{* * *}\end{array}$ & $\begin{array}{c}-2.242 \\
(0.157)^{\star * *}\end{array}$ & $\begin{array}{c}-1.652 \\
(0.191)^{\star * *}\end{array}$ & $\begin{array}{c}-2.163 \\
(0.143)^{\star * *}\end{array}$ & $\begin{array}{c}-1.299 \\
(0.244)^{* * *}\end{array}$ & $\begin{array}{l}-2.302 \\
(0.171)^{* * *}\end{array}$ \\
\hline $\begin{array}{l}\text { Correlation bw. unobservables } \\
\text { Observations }\end{array}$ & & $\begin{array}{l}-.246(.18) \\
24134\end{array}$ & & $\begin{array}{l}-.337(.18) \\
24134\end{array}$ & & $\begin{array}{c}-.225(.17) \\
24134\end{array}$ \\
\hline
\end{tabular}

1. Estimates reported are coefficients of a latent bivariate probit model, selected estimates in Table 7.

2. Standard errors (in parentheses) are corrected for heteroscedasticity and autocorrelation between observations of the same individual.

3. ${ }^{*},{ }^{* *},{ }^{* * *}$ denotes that the coefficient is significantly different from zero at the 10 and 5

and 1 percent confidence level, respectively.

4. Summary statistics of sample shown in Table 2, Panel B

5. "Signing a loan" is a binary variable that takes value 1 if the young adult increased his or her stock of debt by more than 5,000 euro (a) between the first quarter of 1997 and the first quarter of 1999 or (b) between the first quarter of 2000 and the first quarter of 2002.

6 . Log- income of the young adult is the deviation of the labor income of the potential nest-leaver minus its sample mean. Log income of the parent is the deviation of the labor earnings

of the mother and the father of the potential leaver minus its sample mean.

7. Head of household female is a binary variable that takes value 1 if the gender of the head of the origin household of the potential leaver is a female. 


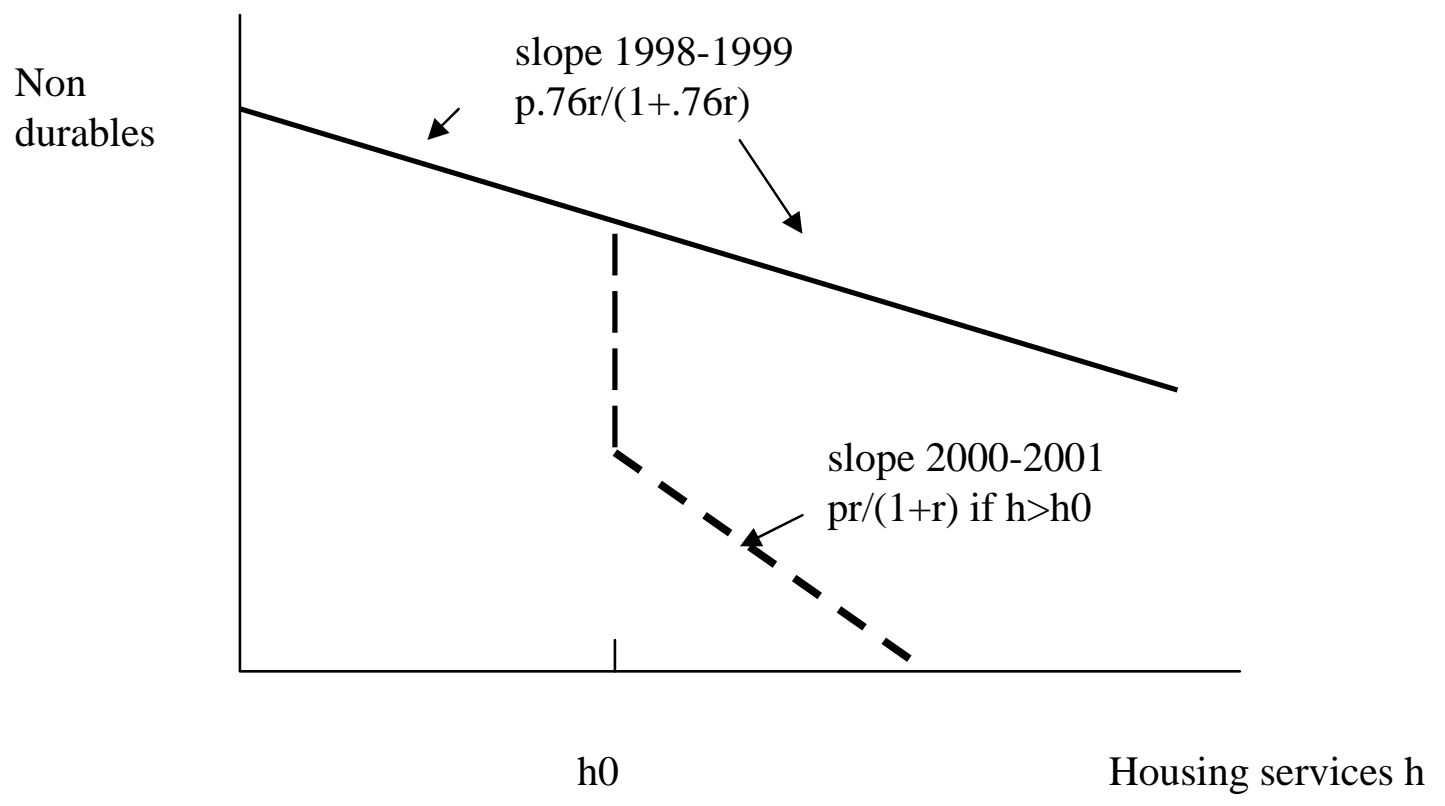

Non

durables

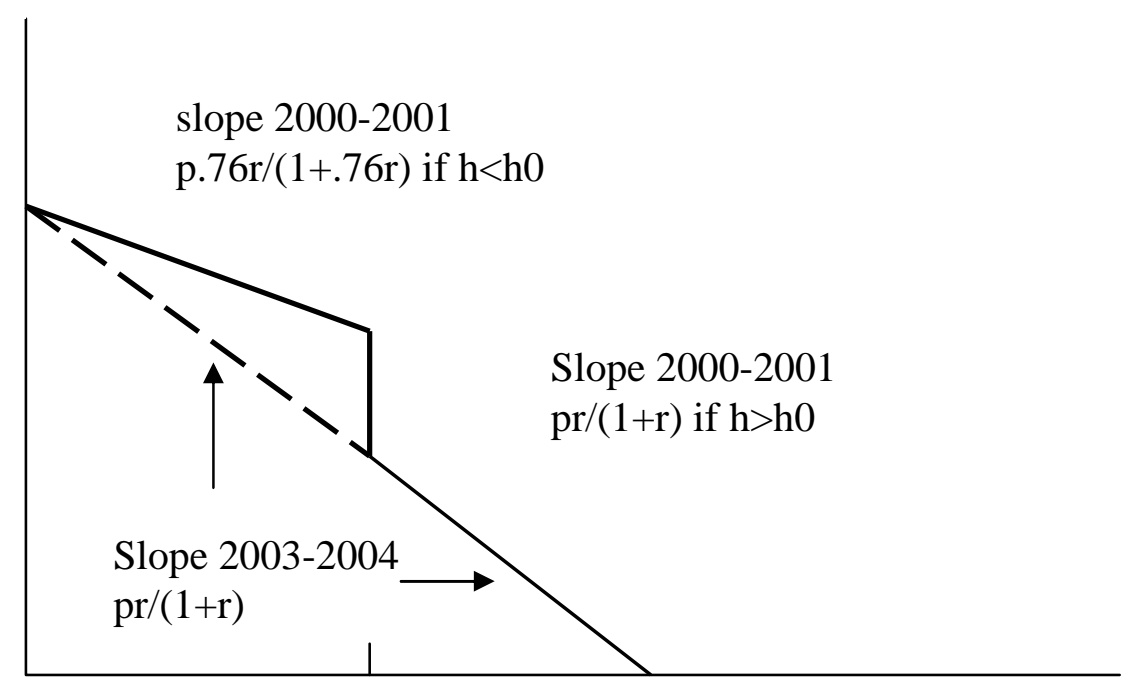

h0

Housing services $h$

Figure 1: Impact on the budget constraint of an eligible individual of the 1999 reform and 2002 cancellation 


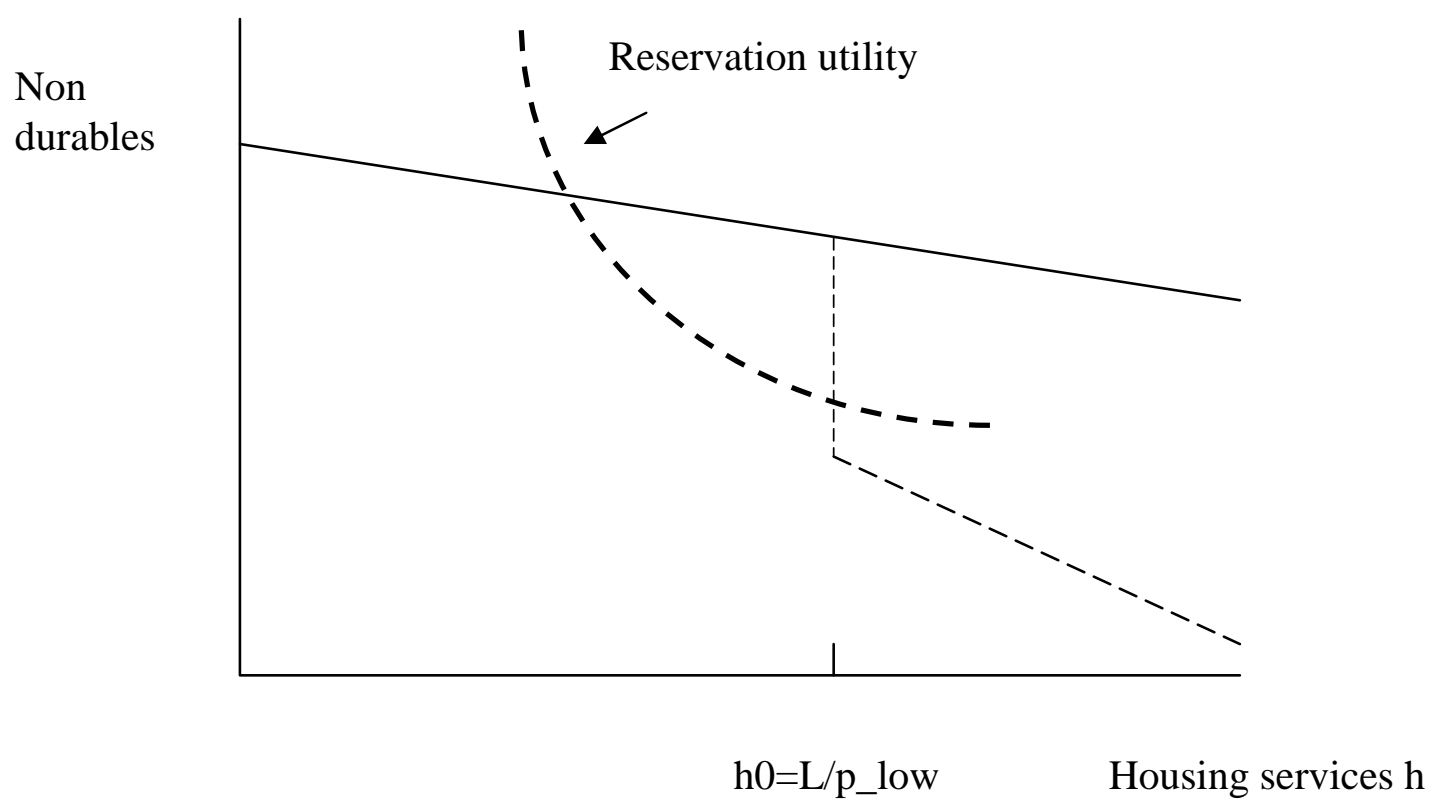

Non

durables

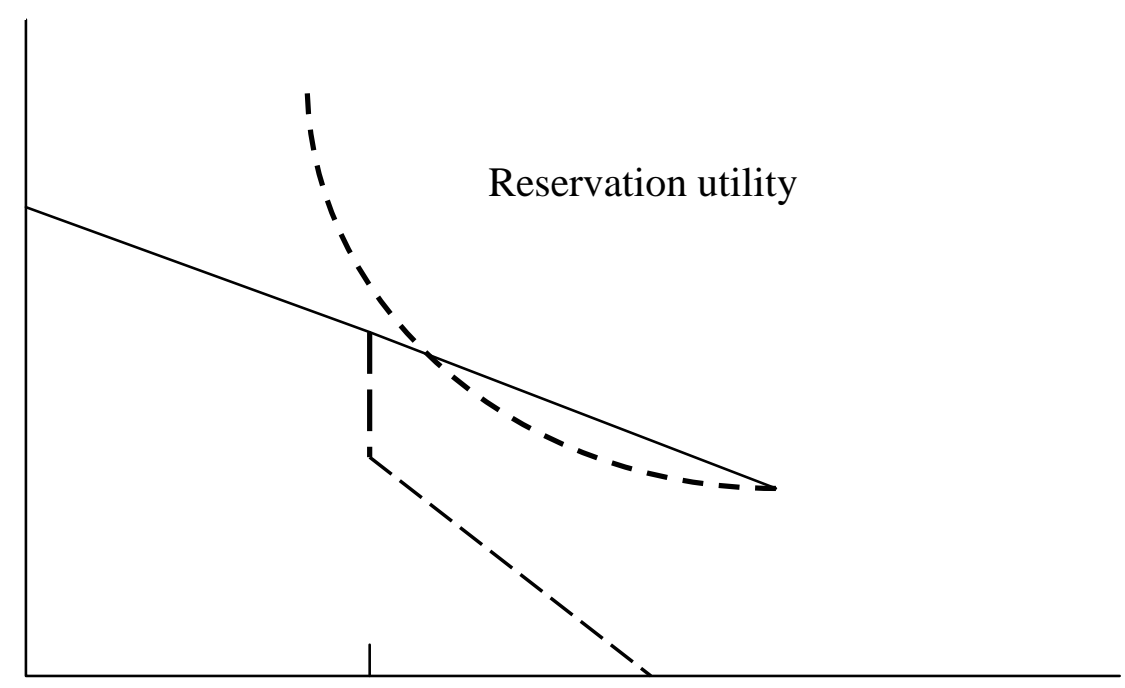

h0=L/p_high

Housing services $h$

Figure 2: Impact of the 1999 reform in a high and low-price region 
BANCO DE ESPAÑA PUBLICATIONS

\section{WORKING PAPERS ${ }^{1}$}

0527 LUIS J. ÁLVAREZ, PABLO BURRIEL AND IGNACIO HERNANDO: Price setting behaviour in Spain: evidence from micro PPI data.

0528 EMMANUEL DHYNE, LUIS J. ÁLVAREZ, HERVÉ LE BIHAN, GIOVANNI VERONESE, DANIEL DIAS, JOHANNES HOFFMANN, NICOLE JONKER, PATRICK LÜNNEMANN, FABIO RUMLER AND JOUKO VILMUNEN: Price setting in the euro area: some stylized facts from individual consumer price data.

0529 TERESA SASTRE AND JOSÉ LUIS FERNÁNDEZ-SÁNCHEZ: Un modelo empírico de las decisiones de gasto de las familias españolas.

0530 ALFREDO MARTÍN-OLIVER, VICENTE SALAS-FUMÁS AND JESÚS SAURINA: A test of the law of one price in retail banking.

0531 GABRIEL JIMÉNEZ AND JESÚS SAURINA: Credit cycles, credit risk, and prudential regulation.

0532 BEATRIZ DE-BLAS-PÉREZ: Exchange rate dynamics in economies with portfolio rigidities.

0533 ÓSCAR J. ARCE: Reflections on fiscalist divergent price-paths.

0534 M. ${ }^{a}$ DE LOS LLANOS MATEA AND MIGUEL PÉREZ: Differences in changes in fresh food prices by type of establishment. (The Spanish original of this publication has the same number.)

0535 JOSÉ MANUEL MARQUÉS, FERNANDO NIETO AND ANA DEL RíO: Una aproximación a los determinantes de la financiación de las sociedades no financieras en España.

0536 S. FABIANI, M. DRUANT, I. HERNANDO, C. KWAPIL, B. LANDAU, C. LOUPIAS, F. MARTINS, T. MATHÄ, R. SABBATINI, H. STAHL AND A. STOKMAN: The pricing behaviour of firms in the euro area: new survey evidence.

0537 LUIS J. ÁLVAREZ AND I. HERNANDO: The price setting behaviour of Spanish firms: evidence from survey data.

0538 JOSÉ MANUEL CAMPA, LINDA S. GOLDBERG AND JOSÉ M. GONZÁLEZ-MíNGUEZ: Exchange-rate pass-through to import prices in the euro area.

0539 RAQUEL LAGO-GONZÁLEZ AND VICENTE SALAS-FUMÁS: Market power and bank interest rate adjustments.

0540 FERNANDO RESTOY AND ROSA RODRÍGUEZ: Can fundamentals explain cross-country correlations of asset returns?

0541 FRANCISCO ALONSO AND ROBERTO BLANCO: Is the volatility of the EONIA transmitted to longer-term euro money market interest rates?

0542 LUIS J. ÁLVAREZ, EMMANUEL DHYNE, MARCO M. HOEBERICHTS, CLAUDIA KWAPIL, HERVÉ LE BIHAN, PATRICK LÜNNEMANN, FERNANDO MARTINS, ROBERTO SABBATINI, HARALD STAHL, PHILIP VERMEULEN AND JOUKO VILMUNEN: Sticky prices in the euro area: a summary of new micro evidence.

0601 ARTURO GALINDO, ALEJANDRO IZQUIERDO AND JOSÉ MANUEL MONTERO: Real exchange rates, dollarization and industrial employment in Latin America.

0602 JUAN A. ROJAS AND CARLOS URRUTIA: Social security reform with uninsurable income risk and endogenous borrowing constraints.

0603 CRISTINA BARCELÓ: Housing tenure and labour mobility: a comparison across European countries.

0604 FRANCISCO DE CASTRO AND PABLO HERNÁNDEZ DE COS: The economic effects of exogenous fiscal shocks in Spain: a SVAR approach.

0605 RICARDO GIMENO AND CARMEN MARTÍNEZ-CARRASCAL: The interaction between house prices and loans for house purchase. The Spanish case.

0606 JAVIER DELGADO, VICENTE SALAS AND JESÚS SAURINA: The joint size and ownership specialization in banks' lending.

0607 ÓSCAR J. ARCE: Speculative hyperinflations: When can we rule them out?

0608 PALOMA LÓPEZ-GARCÍA AND SERGIO PUENTE: Business demography in Spain: determinants of firm survival.

0609 JUAN AYUSO AND FERNANDO RESTOY: House prices and rents in Spain: Does the discount factor matter?

0610 ÓSCAR J. ARCE AND J. DAVID LÓPEZ-SALIDO: House prices, rents, and interest rates under collateral constraints.

0611 ENRIQUE ALBEROLA AND JOSÉ MANUEL MONTERO: Debt sustainability and procyclical fiscal policies in Latin America.

1. Previously published Working Papers are listed in the Banco de España publications calalogue. 
0612 GABRIEL JIMÉNEZ, VICENTE SALAS AND JESÚS SAURINA: Credit market competition, collateral and firms' finance.

0613 ÁNGEL GAVILÁN: Wage inequality, segregation by skill and the price of capital in an assignment model.

0614 DANIEL PÉREZ, VICENTE SALAS AND JESÚS SAURINA: Earnings and capital management in alternative loan loss provision regulatory regimes.

0615 MARIO IZQUIERDO AND AITOR LACUESTA: Wage inequality in Spain: Recent developments.

0616 K. C. FUNG, ALICIA GARCÍA-HERRERO, HITOMI IIZAKA AND ALAN SUI: Hard or soft? Institutional reforms and infraestructure spending as determinants of foreign direct investment in China.

0617 JAVIER DÍAZ-CASSOU, ALICIA GARCÍA-HERRERO AND LUIS MOLINA: What kind of capital flows does the IMF catalyze and when?

0618 SERGIO PUENTE: Dynamic stability in repeated games.

0619 FEDERICO RAVENNA: Vector autoregressions and reduced form representations of DSGE models.

0620 AITOR LACUESTA: Emigration and human capital: Who leaves, who comes back and what difference does it make?

0621 ENRIQUE ALBEROLA AND RODRIGO CÉSAR SALVADO: Banks, remittances and financial deepening in receiving countries. A model.

0622 SONIA RUANO-PARDO AND VICENTE SALAS-FUMÁS: Morosidad de la deuda empresarial bancaria en España, 1992-2003. Modelos de la probabilidad de entrar en mora, del volumen de deuda en mora y del total de deuda bancaria, a partir de datos individuales de empresa.

0623 JUAN AYUSO AND JORGE MARTÍNEZ: Assessing banking competition: an application to the Spanish market for (quality-changing) deposits.

0624 IGNACIO HERNANDO AND MARÍA J. NIETO: Is the Internet delivery channel changing banks' performance? The case of Spanish banks.

0625 JUAN F. JIMENO, ESTHER MORAL AND LORENA SAIZ: Structural breaks in labor productivity growth: The United States vs. the European Union.

0626 CRISTINA BARCELÓ: A Q-model of labour demand.

0627 JOSEP M. VILARRUBIA: Neighborhood effects in economic growth.

0628 NUNO MARTINS AND ERNESTO VILLANUEVA: Does limited access to mortgage debt explain why young adults live with their parents?

\begin{tabular}{|c|c|}
\hline & Unidad de Publicaciones \\
Blcalá, 522; 28027 Madrid \\
BANCODE ESPAÑ & Telephone +34 91 338 6363. Fax +34 91 3386488 \\
e-mail: Publicaciones@bde.es \\
www.bde.es
\end{tabular}




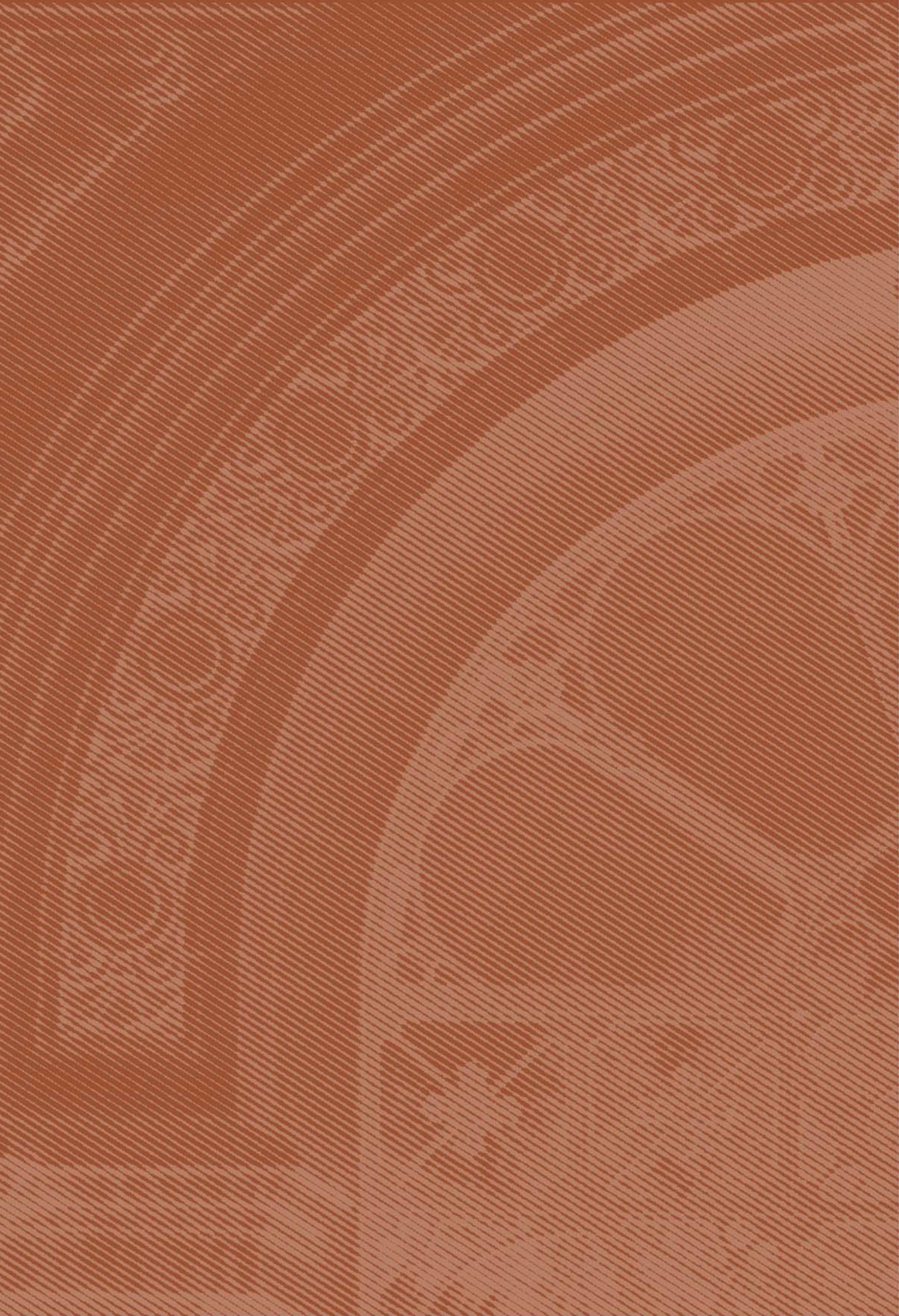

